EFFECTS OF GROUND-W ATER DEVELOPMENT

\title{
ON THE PROPOSED PALMETTO BEND DAM AND RESERVOIR IN SOUTHEAST TEXAS
}

\section{U.S. GEOLOGICAL SURVEY}

Water-Resources Investigations 18-73

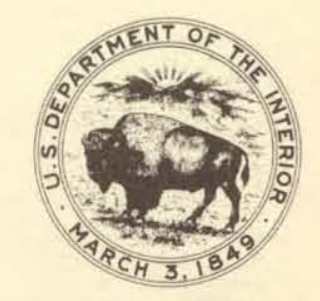

Prepared in cooperation with the U.S. Bureau of Reclamation 


\section{BIBLIOGRAPHIC DATA} SHEET

4. Title and Subtitle

EFFECTS OF GROUND-WATER DEVELOPMENT ON THE PROPOSED PALMETTO

BEND DAM AND RESERVOIR IN SOUTHEAST TEXAS
3. Recipient's Accession No.

5. Report Date

June 1973

6.

8. Performing Organization Rept. No. WRI 18-73

10. Project/Task/Work Unit No.
7. Author(s)
E. T. BAKER, JR. and C. R. FOLLETT

9. Performing Organization Name and Address

U.S. Geological Survey

Federal Building

300 E. 8th Street

Austin, TX 78701

12. Sponsoring Organization Name and Address

U.S. Geological Survey

Federal Building

300 E. 8th Street

Austin, TX 78701
11. Contract/Grant No.

13. Type of Report \& Period Covered

15. Supplementary Notes

16. Abstracts

Ground water continues to discharge into the Navidad and Lavaca Rivers by seepage outflow even though large amounts of ground water are pumped for irrigation. Although a reduction in streamflow probably has occurred, a complete loss of the low flow of the streams by infiltration to a lowered water table seems remote. The large ground-water withdrawals will continue to cause land-surface subsidence, which will range from 0.012 foot to more than 0.026 foot per year. A minimum of about 0.013 to 0.015 foot of annual subsidence at the upper ends of the proposed reservoir and a maximum of about 0.019 foot near the dam site can be expected. Structural failures of manmade features have not occurred from the subsidence, but regional changes in the land slope have occurred and will continue. Numerous fault traces have been mapped in the area, but most of the faults are inactive. If movement along the fault planes should occur, the vertical displacement probably will not exceed the total subsidence.

17. Key Words and Document Analysis. 17a. Descriptors

Water levels/ watertable/ ground-water movement/ infiltration/ inflow/ reservoir inflow/ subsidence/ faulting

17b. Identifiers/Open-Ended Terms

17c. COSATI Field/Group

18. Availability Statement

No restrictions on distribution.

19. Security Class (This Report) UNCLASSIFIED

20. Security Class (This Page

UNCLASSIFIED
21. No. of Pages

22. Price 


\section{EFFECTS OF GROUND-W ATER DEVELOPMENT ON THE PROPOSED PALMETTO BEND DAM AND RESERVOIR IN SOUTHEAST TEXAS}

By E.T. Baker, Jr. and C.R. Follett

\section{U.S. GEOLOGICAL SURVEY}

Water-Resources Investigations 18-73

Prepared in cooperation with the U.S. Bureau of Reclamation

JUNE 1973 


\section{CONTENTS}

Page

Abstract-1.

Introduction-_.

Purpose and objectives of the study-_... 2

Location of the area- 2

Acknowledgments

General physiographic and geologic features of the area-1......- 4

Hydrologic instrumentation and methods of study

Relation of the altitudes of the ground-water levels to the

altitudes of the stream surfaces-ato 17

Problems of interpretation-17

Summary of ground-water conditions at the monitoring sites--- 17

Gains and losses in streamflow-... 21

Navidad River-and 21

Lavaca River.......... 27

Land-surface subsidence-1... 32

Causes and evidence of subsidence-1... 32

Rate and extent of subsidence-1 32

Structural effects of subsidence-1 39

Summary and conclusions-10 39

References cited-1 42

\section{ILLUSTRATIONS}

Figure 1. Map showing location of the study area-1. 3

2. Map showing geology, locations of monitoring sites, wells, and discharge-measurement sites-a 5

3. Section $A-A^{\prime}$ and hydrographs showing altitudes of water levels in wells and stream at Navidad River monitoring site 1-.

4. Section $B-B^{\prime}$ and hydrographs showing altitudes of water levels in wells and stream at Navidad River monitoring site 2

5. Section $\mathrm{C}-\mathrm{C}^{\prime}$ and hydrographs showing altitudes of water levels in wells and stream at Navidad River monitoring site 3....

6. Section $D-D^{\prime}$ and hydrographs showing altitudes of water levels in wells and stream at Navidad River monitoring site 4

7. Section E-E' and hydrographs showing altitudes of water levels in wells and stream at Navidad River monitoring site 5--...

8. Section $\mathrm{F}-\mathrm{F}^{\prime}$ and hydrographs showing altitudes of water levels in wells and stream at Navidad River monitoring site 6-.. 
Abstract-1-0 -

Introduction

Purpose and objectives of the study

Location of the area-.

Acknowledgments -

General physiographic and geologic features of the area-...... Hydrologic instrumentation and methods of study-...-. Relation of the altitudes of the ground-water levels to the

altitudes of the stream surfaces-

Problems of interpretation

Summary of ground-water conditions at the monitoring sites--Gains and losses in streamflow-...

Navidad River

Lavaca River-a-

Land-surface subsidence-1.-

Causes and evidence of subsidence-1

Rate and extent of subsidence

Structural effects of subsidence-1

Summary and conclusions-0

References cited-1.

\section{ILLUSTRATIONS}

Figure 1. Map showing location of the study area-1..-

2. Map showing geology, locations of monitoring sites,

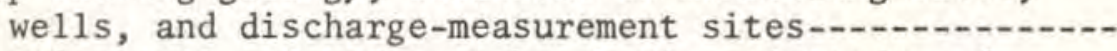

3. Section $A-A^{\prime}$ and hydrographs showing altitudes of water levels in wells and stream at Navidad River monitoring site 1-...

4. Section $B-B^{\prime}$ and hydrographs showing altitudes of water levels in wells and stream at Navidad River monitoring site 2-...

5. Section $\mathrm{C}^{-} \mathrm{C}^{\prime}$ and hydrographs showing altitudes of water levels in wells and stream at Navidad River monitoring site 3-...

6. Section D-D' and hydrographs showing altitudes of water levels in wells and stream at Navidad River monitoring site 4-...

7. Section E-E' and hydrographs showing altitudes of water levels in wells and stream at Navidad River monitoring site 5-..

8. Section F-F' and hydrographs showing altitudes of water levels in wells and stream at Navidad River monitoring site 6 
Figure 9. Section G-G' and hydrographs showing altitudes of water levels in wells and stream at Navidad River monitoring site 7 -

10. Section $\mathrm{H}-\mathrm{H}^{\prime}$ and hydrographs showing altitudes of water levels in wells and stream at Lavaca River monitoring site 1

11. Section $I^{-} I^{\prime}$ and hydrographs showing altitudes of water levels in wells and stream at Lavaca River monitoring site 2-.

12. Hydrograph showing decline of the water level at we11 4 (Lavaca River monitoring site 2) 1936-72 and precipitation at Edna, 1934-71-..-

13. Graph showing streamflow and specific conductance of water, Navidad River, December 14-16, 1970-.....

14. Graph showing streamflow and specific conductance of water, Lavaca River, December 14-17, 1970-....

15. Graphs showing subsidence of selected bench marks in relation to the decline of water levels in nearby wells-..

16. Graphs showing pumpage of ground water for irrigation and irrigated acreage in Jackson County, 1934-71-

17. Graph showing relation of subsidence to water-leve1 decline (1943-72) and thickness of clay interbeds-..18. Map showing thickness of clay interbeds and average annual decline of water levels in the heavily pumped zone in Jackson County and adjacent areas-..-19. Map showing annual amount of predicted landsurface subsidence in Jackson County-... 20. Map showing active or potentially active faults in the southern half of Jackson County-...

\section{TABLES}

Table 1. Description of the stratigraphic units-1...

2. Summary of discharge measurements, Navidad River and tributaries, December 14-16, 1970-1

3. Summary of discharge measurements, Lavaca River

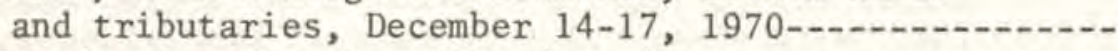

4. Records of wells at monitoring sites-...

5. Drillers' logs of wells at monitoring sites-a-

6. Measurements of water levels in wells and stream-

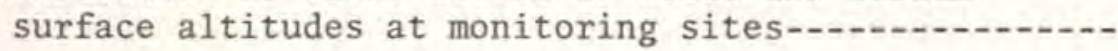


EFFECTS OF GROUND-WATER DEVELOPMENT ON THE PROPOSED PALMETTO BEND DAM AND RESERVOIR IN SOUTHEAST TEXAS

By

E. T. Baker, Jr. and C. R. Follett U.S. Geologica1 Survey

\section{ABSTRACT}

Ground water is discharged into the Navidad and Lavaca Rivers by seepage outflow, which was detected at nine monitoring sites near the two streams. This situation prevailed even during the irrigation season, when ground-water withdrawals normally cause a considerable decline in the water levels. Although the water level in some wells is continuing to decline and is now below the stream level, other wells nearer to the streams indicate that significant rises in the water levels result from periodically heavy rainfall and flooding. This recharge tends to insure seepage outflow of ground water during intervening periods of below-normal rainfall. Even though a complete loss of the low, flow of the streams by infiltration to a lowered water table seems remote, a reduction in streamflow probably has occurred.

The low-flow investigations of the Navidad and Lavaca Rivers support the general conclusion that the streams are gaining flow from groundwater discharge. In the reaches studied, the flow of the Navidad River increased 65 percent from $18.8 \mathrm{cfs}$ (cubic feet per second) to $31.0 \mathrm{cfs}$, or about $0.2 \mathrm{cfs}$ per channel mile; the flow of the Lavaca River increased 800 percent from $4.21 \mathrm{cfs}$ to $37.3 \mathrm{cfs}$, or about $0.5 \mathrm{cfs}$ per channel mile.

Large ground-water withdrawals will continue to cause varying amounts of land-surface subsidence. Subsidence within the mapped area may be expected to range from 0.012 foot to more than 0.026 foot per year. A minimum of about 0.013 to 0.015 foot of annual subsidence at the upper ends of the proposed reservoir and a maximum of about 0.019 foot near the dam site can be expected.

Structural failures of manmade features have not occurred because of the uniform distribution of subsidence, but regional changes in the land slope have occurred and will continue to occur. Numerous fault traces have been mapped in the area, but most of the faults are probably inactive. Any additional vertical displacements along the existing fault planes probably will not exceed the total subsidence. 
Palmetto Bend Dam and Reservoir, a water-supply project to be constructed in two stages by the U.S. Bureau of Reclamation, will impound the waters of the Navidad and Lavaca Rivers in Jackson County, Texas. The project has been in various stages of planning since 1952 when the Jackson County Flood Control District began studies to determine the practicality of damming the Navidad and Lavaca Rivers.

After a private engineering survey was made in 1961, Federal aid was sought through the U.S. Bureau of Reclamation. The Bureau began a feasibility study that was completed in 1963 and designed a reservoir that would impound 192,000 acre-feet of water at an altitude of 44 feet above mean sea level. The final plans were completed in 1964, but a report by the U.S. Geological Survey on the ground-water resources of Jackson County (Baker, 1965), which was published after the Bureau of Reclamation submitted its feasibility report, indicated that large-scale ground-water pumping in the area might significantly affect the low flow of the rivers and increase the rate and amount of land-surface subsidence.

This investigation was made by the U.S. Geological Survey in 1970-72 in cooperation with the U.S. Bureau of Reclamation to determine the effects of large-scale ground-water withdrawals on the proposed dam and reservoir. The specific objectives of the study were (1) to determine if the low flow of the Lavaca and Navidad Rivers might be depleted by infiltration to a lowered water table and (2) to predict the magnitude of landsurface subsidence. These factors are directly related to determination of reservoir inflow and to the design of the dam embankment and spillway.

\section{Location of the Area}

The area studied is in southeast Texas about midway between Houston and Corpus Christi (fig. 1). The area includes parts of Jackson and Lavaca Counties and extends from near the junction of the Lavaca River and the Navidad River in south-central Jackson County northward for about 78 miles to the vicinity of Hallettsville in central Lavaca County. The area of the proposed reservoir is limited to a reach of the two streams in about the central part of Jackson County.

\section{Acknowledgments}

The authors gratefully acknowledge the assistance of $W$. R. Farquhar, Jr., Executive Secretary of the Lavaca-Navidad River Authority, in securing permission to drill wells on county and State rights-of-way, and of Dr. V. E. Barnes and Dr. L. F. Brown, Jr., University of Texas, Bureau of Economic Geology, for providing unpublished geologic and structural maps of the study area. 


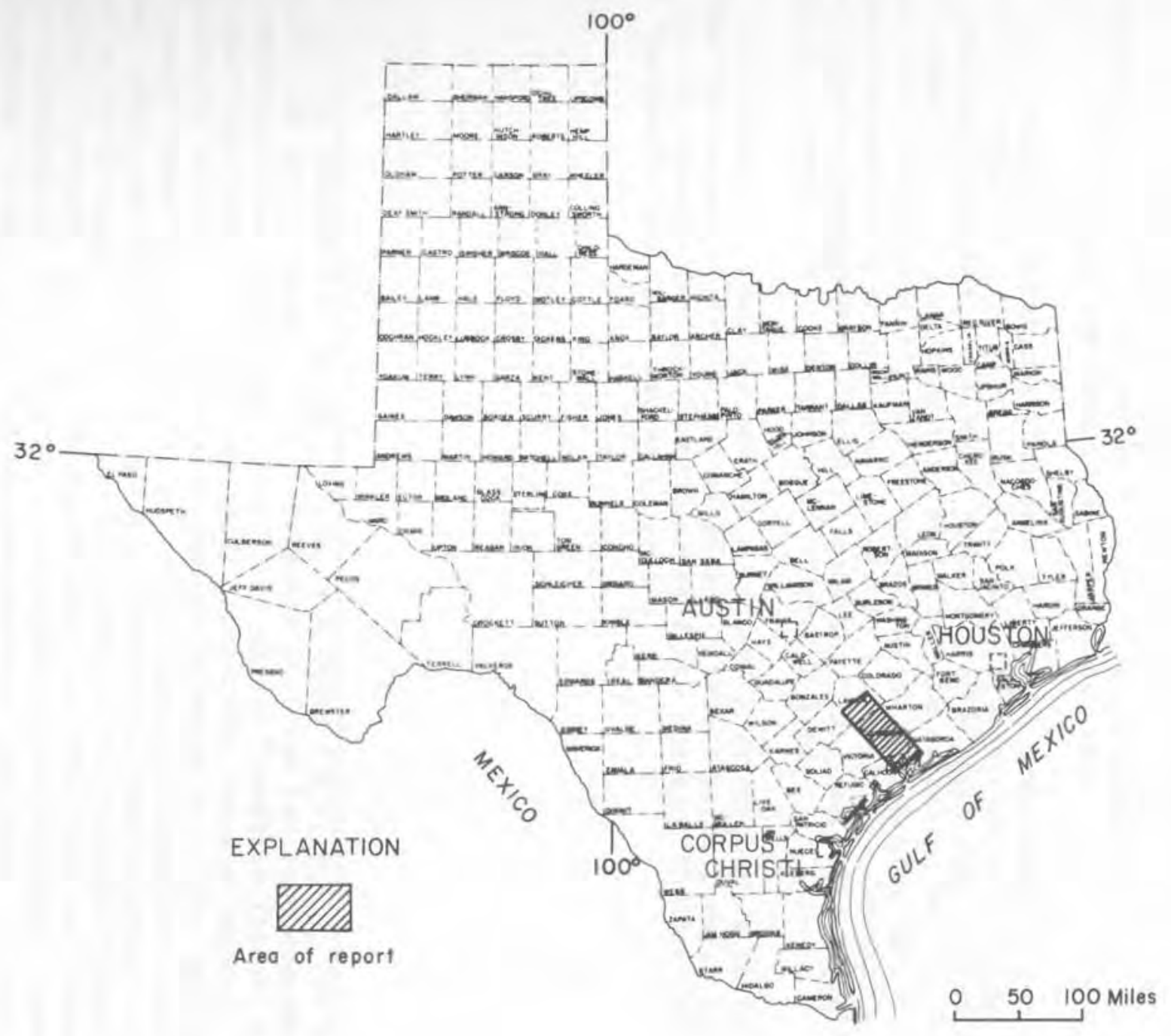

FIGURE I.-Location of the study area 
In the southern three-fourths of the study area, the topography is characterized by the nearly flat Quaternary coastal terraces that have virtually retained their depositional surfaces. In the northern onefourth of the area, the erosional surfaces of the Tertiary formations form a rolling terrain. The area is drained by the Lavaca River and the Navidad River, which is tributary to the Lavaca in south-central Jackson County. The Lavaca River discharges into Lavaca Bay.

The geologic formations that crop out in the area range in age from Miocene to Holocene (fig. 2). They include, from oldest to youngest: The Oakville Sandstone and Fleming Formation of Miocene age; Goliad Sand of Pliocene age; Willis Sand, fluviatile terrace deposits, Bentley Formation, Montgomery Formation, and Beaumont Clay of Pleistocene age $1 /$; and flood-plain alluvium of Holocene age (table 1). Only the fluviatile terrace deposits, Montgomery Formation, Beaumont Clay, and flood-plain alluvium are exposed within the proposed reservoir area.

The geologic formations compose a system of water-bearing units termed the Evangeline and Chicot aquifers. These aquifers, which consist of several thousand feet of lenticular sand and gravel with clay interbeds, are fluviatile to shallow marine in origin.

1/ As indicated by Eargle, Hinds, and Weeks (1971, p. 1), for several decades and until recently, the Pleistocene in Texas has been considered to be composed of two formations, namely, the Lissie Formation (older) and the Beaumont Clay (younger) (Plummer, 1932). Coastwise terrace deposits formerly referred to as the Lissie Formation are now referred to as the Bentley and Montgomery Formations (University of Texas, Bureau of Economic Geology, $1968 \mathrm{a}, 1968 \mathrm{~b}$, and maps in preparation). The Willis Sand has been placed by some in the Pliocene(?) and by Doering (1956) in the Pliocene-Pleistocene interval. Bernard, LeBlanc, and Major (1962, p. 210) place the Willis in the Pleistocene and state that it is equivalent to the Williana Formation (Pleistocene in age) of central and southwestern Louisiana. The Willis is shown as Pleistocene on sheets of the Geologic Atlas of Texas (University of Texas, Bureau of Economic Geology, 1968a, 1968b, and maps in preparation). Mapping of the Pleistocene for the Atlas was done by Dr. Saul Aronow of Lamar University, Beaumont, Texas. In view of this recent mapping of the Coastal Plain of Texas by the University of Texas, Bureau of Economic Geology and of supporting evidence from other sources, the age of the Willis Sand is hereby changed from Pliocene(?) to Pleistocene. 


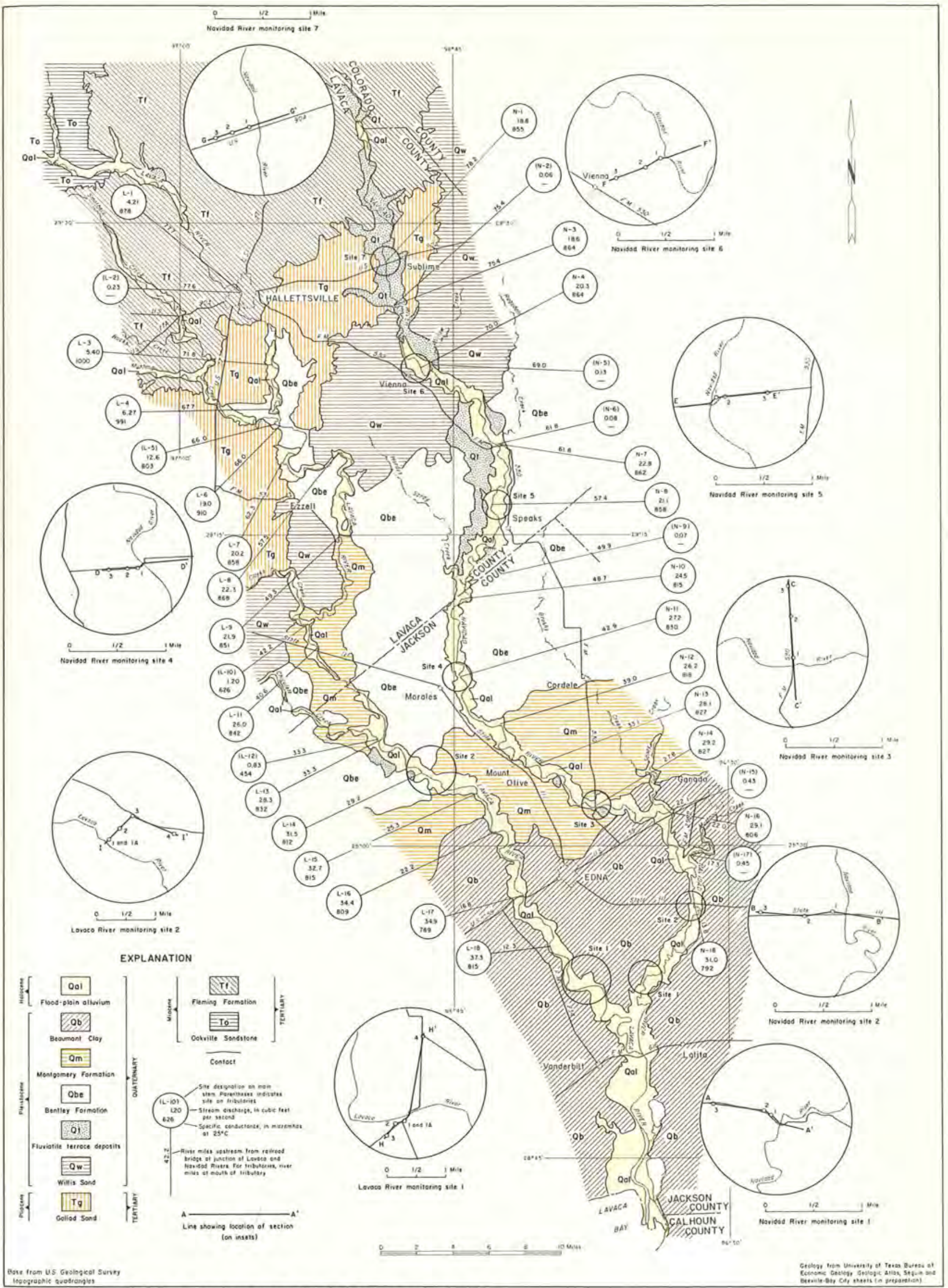

FIGURE 2.-Geology, locations of monitoring sites, wells, and discharge-measurement sites 
Table 1.--Description of the stratigraphic units

\begin{tabular}{|c|c|c|c|}
\hline System & Series & Stratigraphic unit & Lithology \\
\hline \multirow{6}{*}{ Quaternary } & Holocene & $\begin{array}{l}\text { Flood-plain } \\
\text { alluvium }\end{array}$ & $\begin{array}{l}\text { Clay, silt, fine to very coarse sand, } \\
\text { and gravel. }\end{array}$ \\
\hline & \multirow{5}{*}{ Pleistocene } & $\begin{array}{l}\text { Beaumont } \\
\text { Clay }\end{array}$ & $\begin{array}{l}\text { Mostly clay, silt, and fine sand. Some } \\
\text { very fine, medium, and coarse sand and } \\
\text { gravel. }\end{array}$ \\
\hline & & $\begin{array}{l}\text { Montgomery } \\
\text { Formation }\end{array}$ & $\begin{array}{l}\text { Mostly clay, silt, and fine sand. Some } \\
\text { medium sand and gravel. }\end{array}$ \\
\hline & & $\begin{array}{l}\text { Bentley } \\
\text { Formation }\end{array}$ & $\begin{array}{l}\text { Mostly fine sand, silt, and clay. Some } \\
\text { very fine and medium to coarse sand and } \\
\text { gravel. }\end{array}$ \\
\hline & & $\begin{array}{c}\text { Fluviatile terrace } \\
\text { deposits }\end{array}$ & $\begin{array}{l}\text { Mostly fine sand, but some medium and } \\
\text { coarse sand and gravel. }\end{array}$ \\
\hline & & Willis Sand & $\begin{array}{l}\text { Mostly fine sand, silt, and clay. Some } \\
\text { medium to coarse sand and gravel. }\end{array}$ \\
\hline \multirow{3}{*}{ Tertiary } & Pliocene & Goliad Sand & $\begin{array}{l}\text { Fine to coarse sand, calcareous clay, } \\
\text { silt, and gravel. }\end{array}$ \\
\hline & \multirow{2}{*}{ Miocene } & $\begin{array}{l}\text { Fleming } \\
\text { Formation }\end{array}$ & $\begin{array}{l}\text { Mostly clay interbedded with sand and } \\
\text { sandstone. Clay is silty and commonly } \\
\text { calcareous. }\end{array}$ \\
\hline & & $\begin{array}{l}\text { Oakville } \\
\text { Sandstone }\end{array}$ & $\begin{array}{l}\text { Mostly medium sand and thinly bedded } \\
\text { calcareous clay. Reworked Cretaceous } \\
\text { fossils locally abundant. }\end{array}$ \\
\hline
\end{tabular}


From three to five shallow wells were drilled at each of nine monitoring sites in and near the valleys of the Lavaca and Navidad Rivers from about $1 \mathrm{mile}$ above the proposed dam site in Jackson County to U.S. Highway $90 \mathrm{~A}$ in Lavaca County (fig. 2). Seven of the nine monitoring sites were along the Navidad River--the first stream scheduled to be dammed in the proposed two-stage construction program.

These wells, which were drilled to observe fluctuations of the water table and its relation to the altitudes of the stream surfaces, were alined perpendicular to the stream channel and were spaced a few hundred to a few thousand feet apart. At each study site, the wells were numbered consecutively beginning with 1 , well 1 being closest (200 to 800 feet) to the stream. When an alternate we11 was drilled next to another well, the alternate well was given an alphabetical designation, such as 1-A.

Each well was drilled to a depth several feet or several tens of feet below the water table; depths of the wells ranged from 19 to 71 feet below land surface. The wells, which were drilled with a 4-inch solid-stem, continuous-flight auger, were cased with 1 -inch (inside diameter) black iron pipe perforated in the bottom 10 feet (table 4). The sand beds that were considered suitable for screening were determined from drillers' logs (table 5).

The changes in the stages of the streams were measured from reference marks on bridges. Spirit leveling at each monitoring site related the wells and streams to a common arbitrary datum. Measurements of depths to the water in the wells and stages of the streams were made mostly at 5week intervals over a period of 20 months (table 6 ).

Low-flow investigations of the Lavaca and Navidad Rivers were made in December 1970 to determine gains or losses in flow and to relate the gains or losses to the altitude of the contiguous shallow water levels. The low-flow measurements were made from U.S. Highway $90 \mathrm{~A}$ in Lavaca County to sites 4 to 6 miles south and east of Edna in Jackson County (fig. 2). Streamflow was measured at 36 sites along the main stem of the streams and their tributaries.

Measurements of water levels in relatively deep wells tapping the Evangeline or Chicot aquifers, supplemented by previous water-level measurements, were made to relate the magnitude and rate of water-leve 1 decline to pumpage and land-surface subsidence. The ratio of subsidence to water-level decline and thickness of clay interbeds was used for predicting the magnitude of future subsidence. 

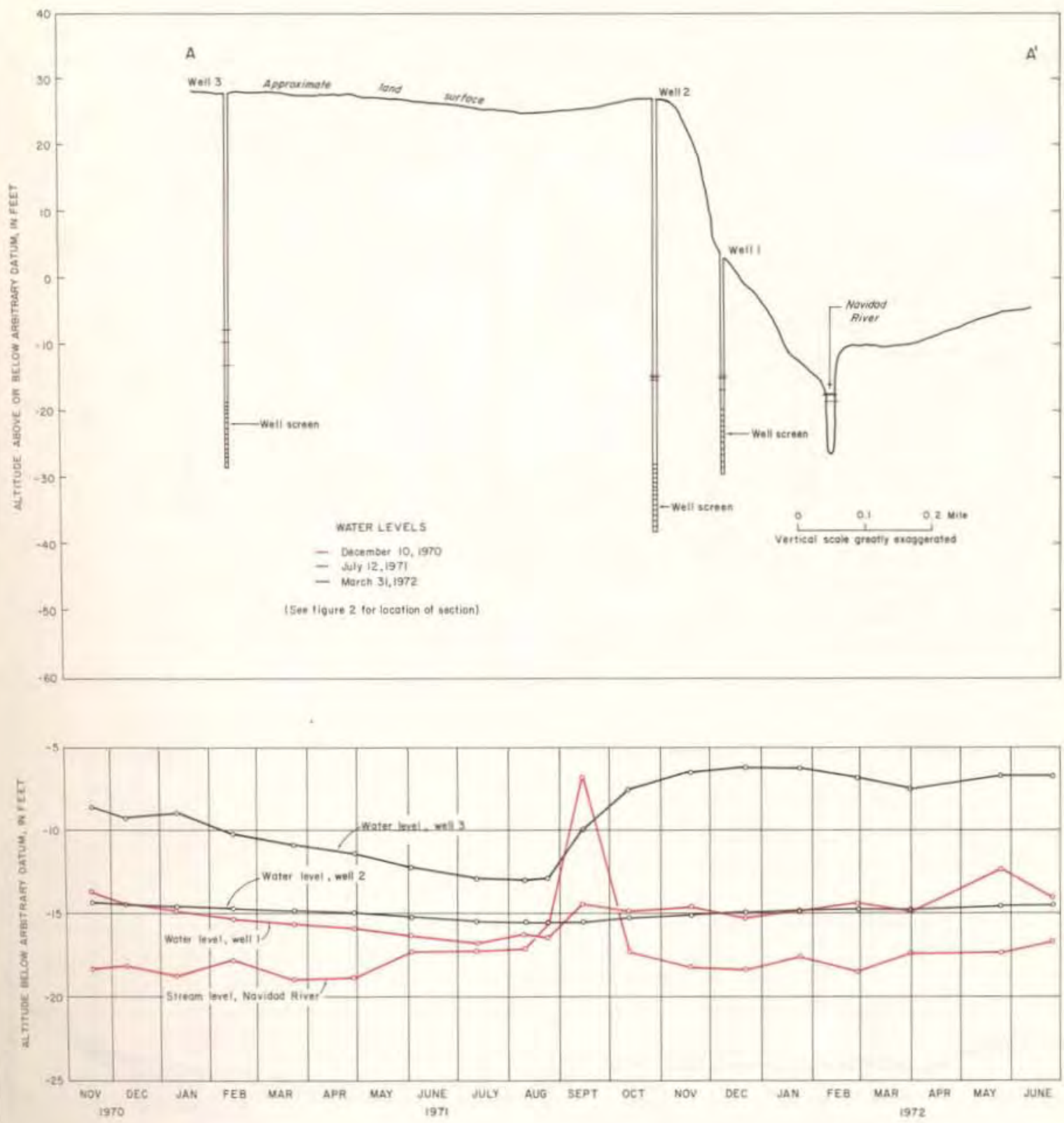

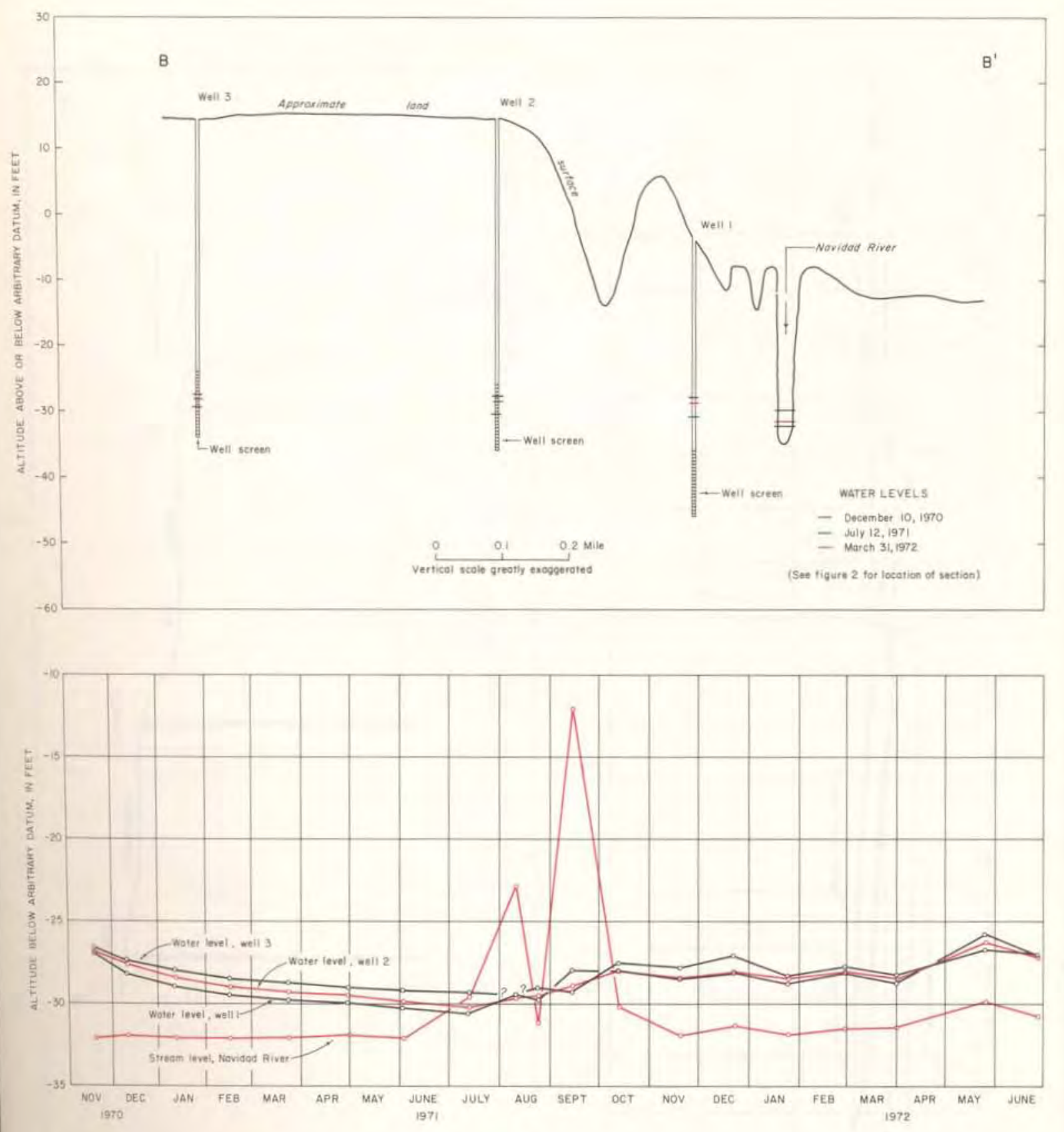

FIGURE 4. -Altitudes of water levels in wells and stream at Navidad River monitoring site 2 

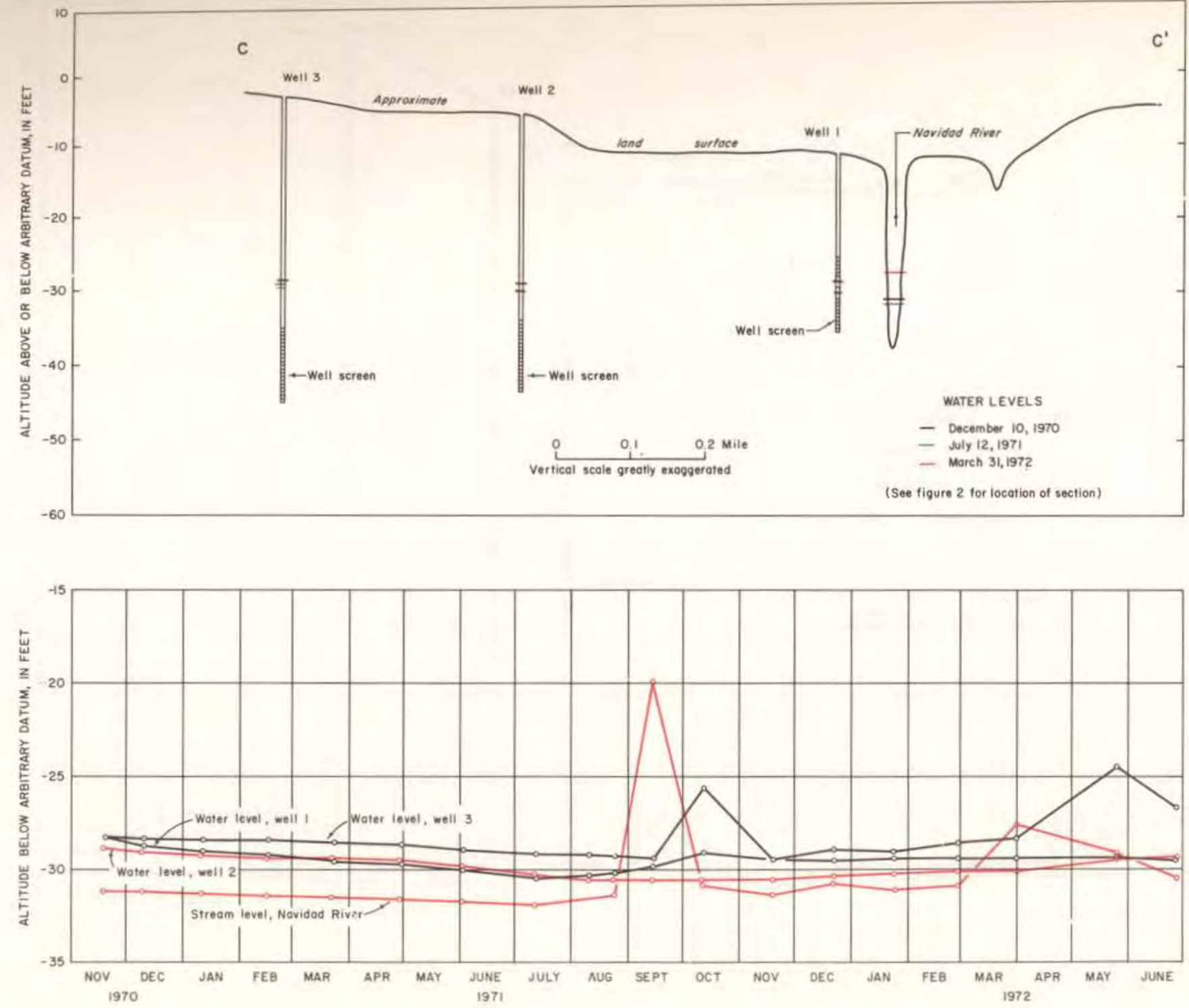

FIGURE 5.-Altitudes of water levels in wells and stream at Navidad River monitoring site 3 

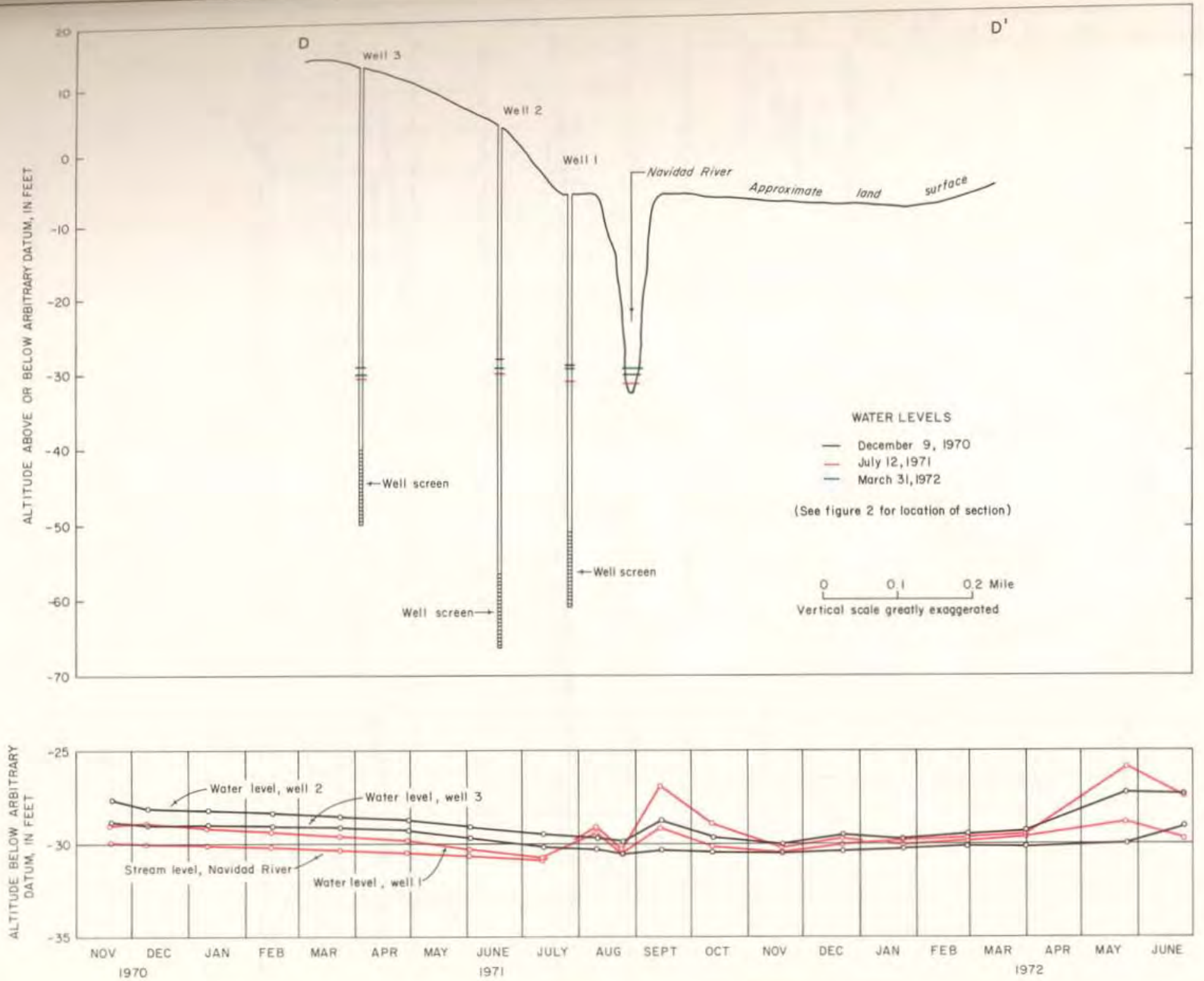

FIGURE 6.-Altitudes of water levels in wells and stream at Navidad River monitoring site 4 

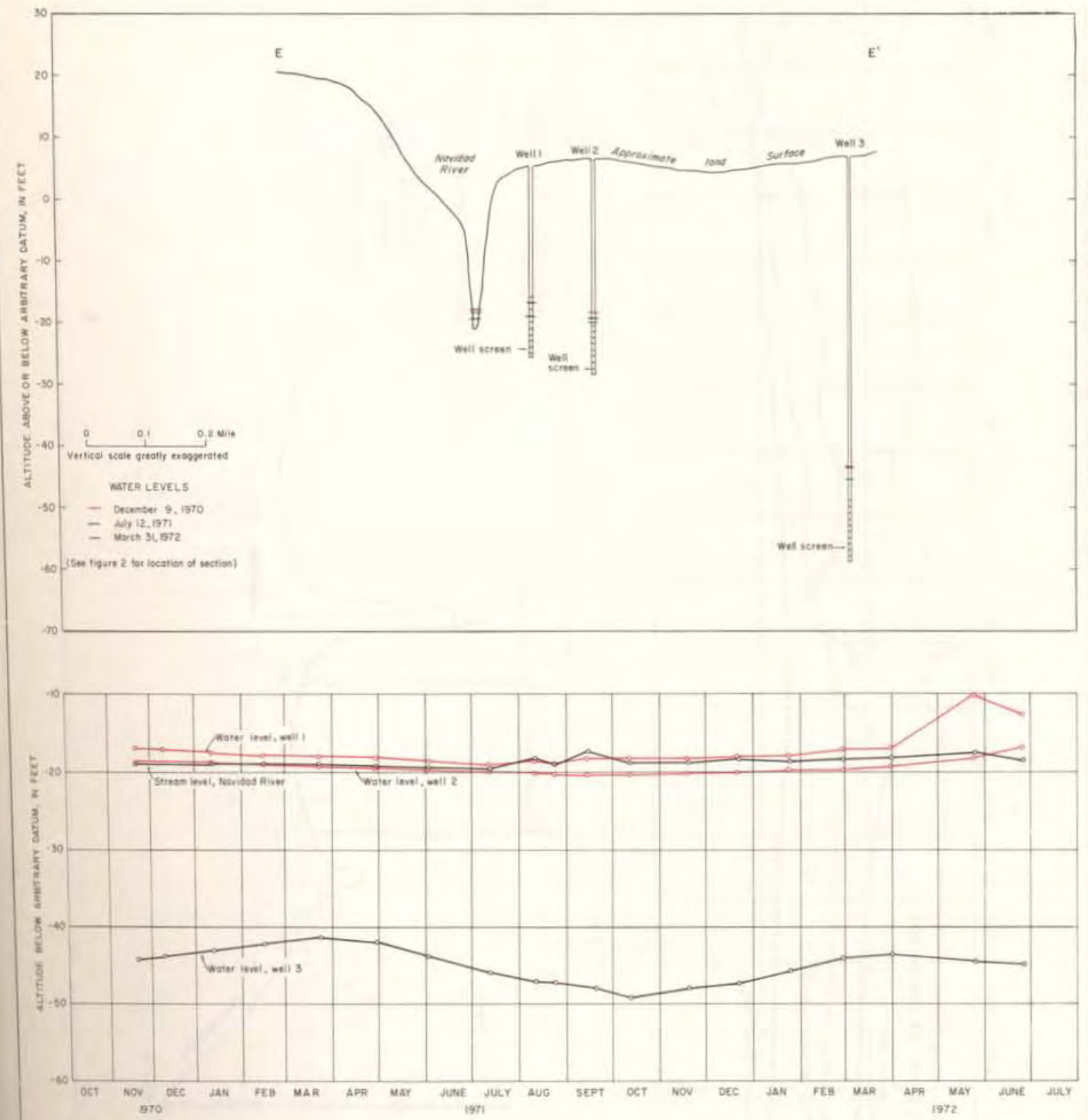


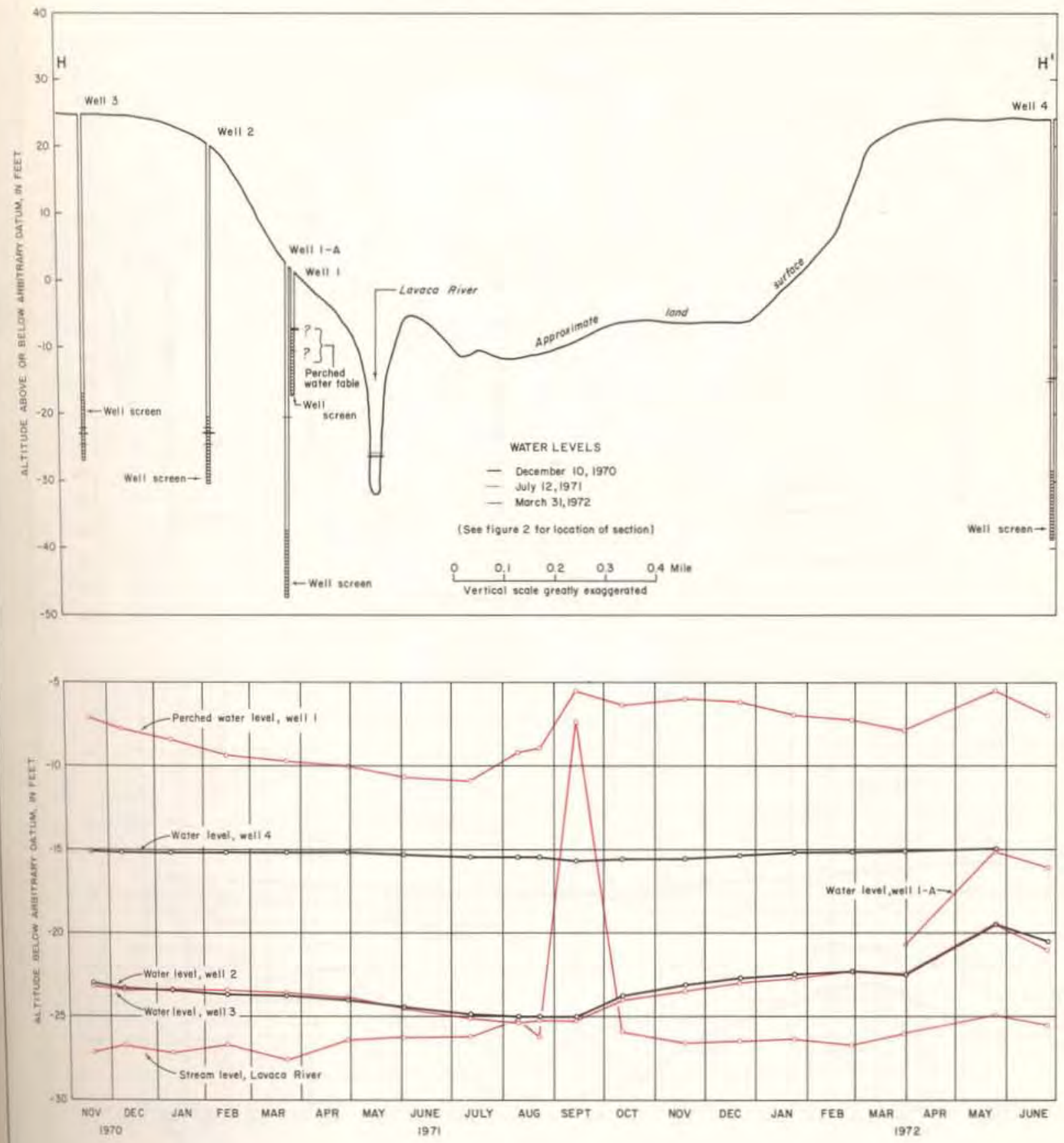

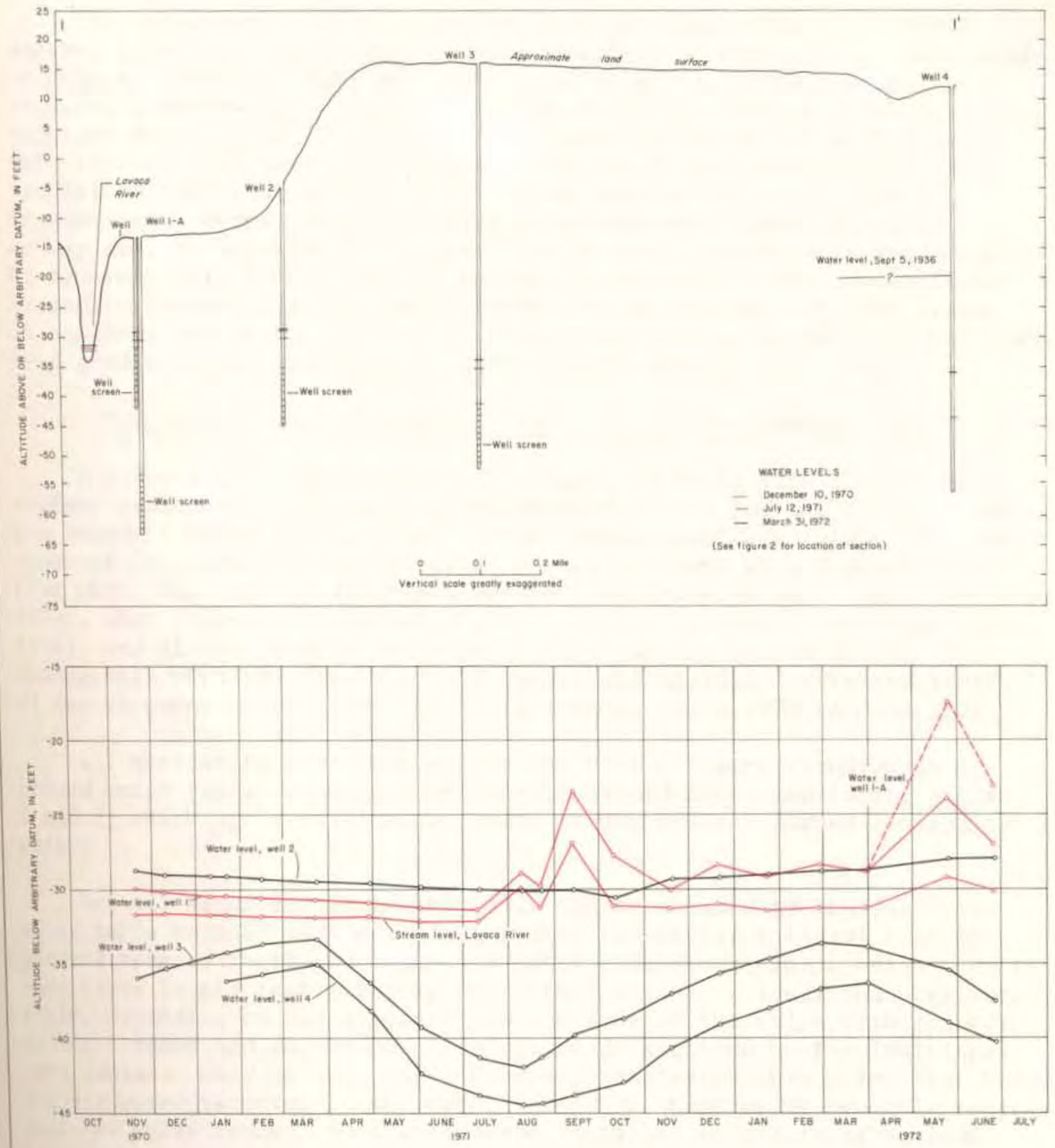
RELATION OF THE ALTITUDES OF THE GROUND-WATER LEVELS

TO THE ALTITUDES OF THE STREAM SURFACES

Problems of Interpretation

The interpretation of water levels in shallow wells of different depths, especially in a heterogeneous aquifer, is complex. As indicated by Hubbert (1940, p. 930) and Lohman (1972, p. 7), ground-water flow acquires a three-dimensional pattern in uniformly permeable material that receives recharge in interstream areas and from which water discharges into streams. In this idealized setting, which is similar but greatly simplified from that of the report area, cased wells at or near the streams reach water under greater head as the well depth increases. Conversely, at and near the interstream divides, cased wells reach water at progressively lower heads as the depth increases. The low vertical hydraulic conductivity of the interbedded clay between the sand lenses in and near the stream valleys of the report area accentuate the verticalhead gradients and make interpretation difficult.

\section{Summary of Ground-Water Conditions at the Monitoring Sites}

The sections and hydrographs in figures 3 to 11 show the streamsurface altitudes of the Lavaca and Navidad Rivers and the altitudes of the adjacent water levels plotted to a common arbitrary datum. The altitudes of the water levels indicated on the sections were measured at a time when evapotranspiration and ground-water pumpage were small (December 1970), when evapotranspiration and ground-water pumpage were large (July 1971), and at an intermediate time in early spring (March 1972). The hydrographs show the levels of the Lavaca and Navidad Rivers and levels of the adjacent water levels in wells from November 1970 to June 1972 .

Al1 monitoring sites are within the area of large withdrawals of ground water for rice irrigation except Navidad River monitoring sites 6 and 7 , which are several miles north of any heavily pumped irrigation wells.

Not all water levels in the wells can be assumed to represent the water table because some wells penetrated too deeply (several feet to several tens of feet) below the air-water interface. These wells tend to have water levels that probably are either higher or lower than the water table, depending on the distance and altitude of the wells with respect to the streams and on various pressure heads acquired by the individual sand lenses. Many of the wells, however, penetrated only a few feet below the air-water interface. The water levels in these wells probably represent the water table. Such wells were installed in places at Navidad River monitoring sites 2, 3, and 5 (figs. 4, 5, and 7) and at Lavaca River monitoring sites 1 and 2 (figs. 10 and 11). 
With few exceptions, ground-water levels in wells at the monitoring sites were higher than the low-flow surfaces of the streams throughout the 19-month period of observation. The relatively high standing levels persisted even during the hot summer months when evapotranspiration and ground-water pumpage were large. Only in a few wells, mainly those relatively far from the streams at Navidad River monitoring site 5 (fig. 7) and Lavaca River monitoring site 2 (fig. 11), did the water levels fluctuate frequently below stream level.

The cyclic fluctuations of the water levels in well 3 at Navidad River monitoring site 5 (fig. 7), and in wells 3 and 4 at Lavaca River monitoring site 2 (fig. 11), which correspond closely with the seasonal irrigation pumpage, indicate relatively good hydraulic continuity between the shallow and deeper aquifers in the local areas of these wells.

Heavy ground-water pumpage in Jackson and Lavaca Counties for irrigation from late March to early August 1971 caused a large reduction in artesian pressure in the deep and heavily pumped zone. This decline in pressure, in turn, caused an increase in the downward movement of the shallow ground water and resulted in a rapid decline of the water levels in these wells during the spring and summer months of 1971 . Thereafter, until March 1972, the water levels rose in response to a buildup in artesian pressure. This downward movement of shallow ground water was first detected in 1963 by a spinner survey on an irrigation well south of Ganado (Baker, 1965, p. 9 and 11).

Since the early 1940 's, when irrigation pumpage in Jackson and Lavaca Counties began to increase substantially, artesian pressure in the heavily pumped zone has decreased. As a result the water table has declined and shallow sands in many places have been dewatered. The fluctuation of the water level in well 4 , as illustrated by the hydrograph in figure 12, is due to rainfall and related increases or decreases in irrigation pumpage. However, since the early $1940^{\prime} \mathrm{s}$, rainfall has been unable to stabilize the decline.

Between September 1936 and June 1972, the water leve1 in we11 4 has declined at least 25 feet, although about one-third of this decline is temporary and is recovered after the end of the irrigation season (fig. 12). The net decline, however, has been sufficient to change the regional position of the shallow ground-water levels at Lavaca River monitoring site 2 (and probably elsewhere in some areas of heavy ground-water pumpage) from being persistently higher than the stream level to being partly lower than the stream level (fig. 11). This change is significant because the reduction in the regional gradient of the shallow water levels toward the stream probably has reduced seepage outflow and consequently decreased the streamflow. The rate of the probable decrease in streamflow is not known, 

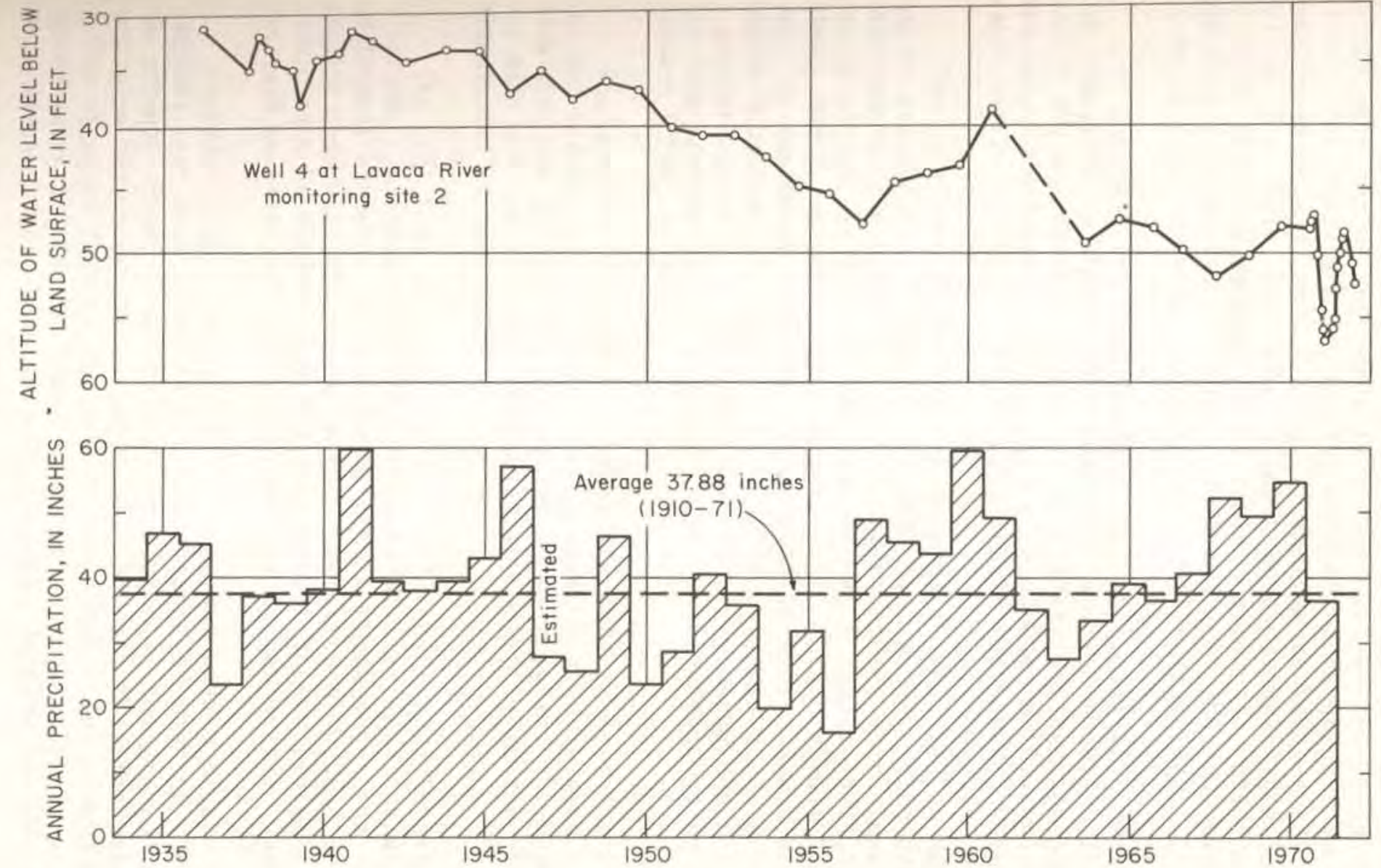

FIGURE 12.-Decline of the water level at well 4 (Lavaca River monitoring site 2) 1936-72 and precipitation at Edna, 1934-71 
Low vertical hydraulic conductivity, which causes poor hydraulic connection of the shallow beds with the deeper beds, may be demonstrated by the behavior of the water levels in most of the wells at the monitoring sites. Extremely poor hydraulic connection is evident at Navidad River monitoring site 7, we11 2 (fig. 9) and Lavaca River monitoring site 1, well 1 (fig, 10). Both wells, which were properly functioning when tested, probably tapped a perched water table. Alternate well 1-A, which was a few feet from we11 1 but about 30 feet deeper, had a water level from 10 to 15 feet below the perched water table (fig. 10).

At Lavaca River monitoring site 2 (fig. 11) alternate well 1-A, which was completed in the Bentley Formation and was about 20 feet deeper than well 1 (in the flood-plain alluvium), revealed that the pressure head in the deeper sand was slightly higher than that in the shallower sand. The water levels in the two wells were nearly the same on March 31, 1972.

The considerably higher water level in well 1-A in May and June 1972 may be attributed largely to the fact that a short time prior to the May measurement, flood water from the Lavaca River, which covered the well casing of only we11 1-A (oral commun., R. L. Goss, 1972), admitted a steady supply of water into the well through a breather hole in the casing cap. By September 1972 the water level in well 1-A was only 1.23 feet higher than that in well 1 . The higher pressure head in well 1-A implies a greater upward component of flow with increasing depth in accordance with the flow pattern near a site of ground-water discharge as suggested by Hubbert (1940, p. 930).

The absence of a zone of lower pressure in well 1-A such as that encountered in wells 3 and 4, which have relatively good hydraulic connection with the deeper heavily pumped zone, suggests the presence of confining beds and low vertical hydraulic conductivity in the shallow aquifer beneath the stream valley.

The fact that most of the test wells had water levels that did not fluctuate cyclically with the seasonal decline in artesian pressure is additional evidence of widespread poor connection of the shallow waterbearing beds with the deeper ones. Low vertical hydraulic conductivities within much of the shallow aquifer support the water table by retarding downward movement of the water into the deeper heavily pumped zone.

Periodic high flows of the Navidad and Lavaca Rivers and substantial rainfall have been shown by the hydrographs of most of the wells near the streams (figs. 3-11) to quickly replenish the ground water in storage and raise the water levels especially beneath the flood plains. A combination of these factors is largely responsible for maintaining shallow ground-water levels, at least within the river valleys, at an altitude above stream level, thus insuring seepage outflow to the streams. 
Low-flow investigations of the Navidad and Lavaca Rivers were made during December 14-17, 1970, to determine gains or losses in streamflow. During this period, evapotranspiration and ground-water pumpage were minimal. Records from U.S. Geological Survey stream-gaging stations at the upper and lower ends of the reaches investigated showed that the measurements were started from 34 to 42 days after low-flow conditions on the two streams had been established. No rain fell during the 4-day period of discharge measurements, which were made at 36 sites along the main stems and at points of inflow from tributaries. No diversions were noted during the investigations.

\section{Navidad River}

The low-flow investigation of the Navidad River was made from the crossing on U.S. Highway $90 \mathrm{~A}$ near Sublime to the crossing on State Highway 111 south of Ganado, a distance of 64.4 river miles. The lower end of the reach is 13.8 miles upstream from the railroad bridge at the junction of the Lavaca and Navidad Rivers. The main stem of the Navidad River flows in a bed of flood-plain alluvium in all of the reach except in the upper 5 miles, where fluviatile terrace deposits are exposed in the channe 1 (fig. 2).

The investigation showed that the Navidad River had mostly small to moderate gains in flow and a few small to moderate losses (table 2). Over the 64.4-mile reach of the channe1, streamflow increased from 18.8 cfs (cubic feet per second) at the upper end (site $\mathrm{N}-1$ ) to $31.0 \mathrm{cfs}$ at the lower end (site $\mathrm{N}-18$ ). This is an increase in flow of 65 percent and an average increase per channel mile of almost $0.2 \mathrm{cfs}$. Mustang and Sandy Creeks, which had a combined flow of $0.88 \mathrm{cfs}$, were the largest contributors of water to the Navidad River and accounted for 80 percent of the tributary inflow.

With the exception of indicated losses in streamflow between miles 78.2 and $75.4,61.8$ and $57.4,42.9$ and 39.0 , and 27.8 and 22.0 , greater increases in flow per channel-mile occurred in the upper half of the reach than in the lower half (fig. 13). A reduction in the rate of gain in streamflow occurred below mile 42.9 , or below Navidad River monitoring site 4. This reduced rate of gain in the lower reach is attributed to a lower transmissivity of the flood-plain alluvium.

Some of the indicated streamflow losses may be accounted for by possible measurement error and others may be due to the lower altitude of the water table adjacent to the stream within the four losing reaches. This relationship was not observed by test drilling, however, because all seven of the monitoring sites showed that the water table, at least in the zone between well 1 and the Navidad River, was sloping toward the stream. 


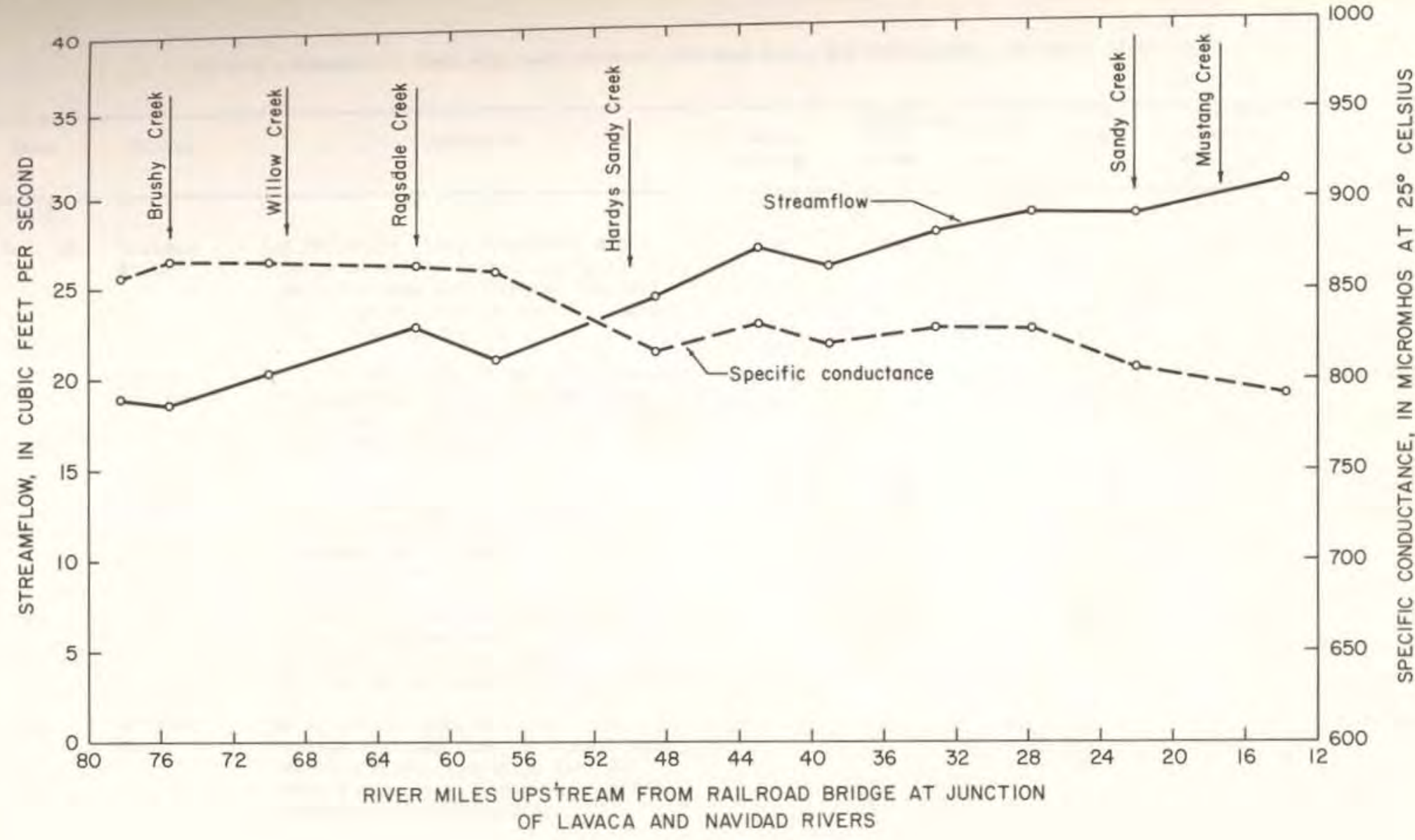

FIGURE 13.-Streamflow and specific conductance of water, Navidad River, December 14-16, 1970 
Table 2.--Sumary of discharge measurements, Navidad River and tributaries, December 14-16, 1970

\begin{tabular}{|c|c|c|c|c|c|c|c|c|c|}
\hline $\begin{array}{c}\text { Site } \\
\text { no. }\end{array}$ & Date & Stream & Location & $\begin{array}{l}\text { River } \\
\text { mile a/ }\end{array}$ & $\begin{array}{l}\frac{\text { Discharge }}{\text { Main }} \\
\text { stream }\end{array}$ & $\begin{array}{l}\text { in cfs } \\
\text { Tribur } \\
\text { tary }\end{array}$ & $\begin{array}{l}\text { Water } \\
\text { temp. } \\
\left({ }^{\circ} \mathrm{C}\right)\end{array}$ & $\begin{array}{l}\text { Specific } \\
\text { conductance } \\
\text { (micromhos } \\
\text { at } 25^{\circ} \mathrm{C} \text { ) }\end{array}$ & Remarks \\
\hline & 1970 & & & & & & & & \\
\hline$N-1$ & Dec. 14 & $\begin{array}{l}\text { Navidad } \\
\text { River }\end{array}$ & $\begin{array}{l}\text { Lat } 29^{\circ} 28^{\prime} 02^{\prime \prime} \text {, long } 96^{\circ} 48^{\prime} 40^{\prime \prime}, 400 \mathrm{ft} \\
\text { downstream from stream-gaging station } \\
08164300 \text { near U.S. Highway } 90 \mathrm{~A}, 1.0 \\
\text { mile west of Sublime, and } 8.0 \mathrm{miles} \\
\text { east of Hallettsville. }\end{array}$ & 78.2 & 18.8 & $\cdots$ & $\ldots$ & 855 & \\
\hline $\mathrm{N}-2$ & do & $\begin{array}{l}\text { Brushy } \\
\text { Creek }\end{array}$ & $\begin{array}{l}\text { Lat } 29^{\circ} 25^{\prime} 55^{\prime \prime} \text {, Iong } 96^{\circ} 48^{\prime} 11^{\prime \prime} \text {, upstream } \\
\text { from confluence with Navidad River, } \\
2.7 \text { miles south of Sublime, and } 8.5 \\
\text { miles east of Hallettsville. }\end{array}$ & b/ 75.4 & $\cdots$ & 0.06 & 15.0 & $\ldots$ & Flow estimated. \\
\hline $\mathrm{N}-3$ & do & $\begin{array}{l}\text { Navidad } \\
\text { River }\end{array}$ & $\begin{array}{l}\text { Lat } 29^{\circ} 25^{\prime} 56^{\prime \prime} \text {, long } 96^{\circ} 48^{\prime} 06^{\prime \prime} \text {, just } \\
\text { downstream from confluence with } \\
\text { Brushy Creek, } 2.7 \text { miles south of } \\
\text { Sublime, and } 8.5 \text { miles east of } \\
\text { Hallettsville. }\end{array}$ & 75.4 & 18.6 & $\ldots$ & 13.5 & 864 & $\begin{array}{l}\text { Fairly uniform } \\
\text { channel. }\end{array}$ \\
\hline$N-4$ & do & do & $\begin{array}{l}\text { Lat } 29^{\circ} 22^{\prime} 55^{\prime \prime}, \text { long } 96^{\circ} 46^{\prime} 45^{\prime \prime}, 100 \mathrm{ft} \\
\text { downstream from county bridge, } 0.8 \\
\text { mile east of Vienna community, and } \\
10.6 \text { miles southeast of Hallettsville. }\end{array}$ & 70.0 & 20.3 & .. & 13.5 & 864 & \\
\hline$N-5$ & do & $\begin{array}{l}\text { Willow } \\
\text { Creek }\end{array}$ & $\begin{array}{l}\text { Lat } 29^{\circ} 23^{\prime} 04^{\prime \prime}, \text { long } 96^{\circ} 46^{\prime} 12^{\prime \prime} \text {, at county } \\
\text { bridge upstream from confluence with } \\
\text { Navidad River, } 1.4 \text { miles east of } \\
\text { Vienna community, and about } 6 \text { miles } \\
\text { southeast of Hallettsville. }\end{array}$ & b/ 69.0 & -. & .013 & -- & $\ldots$ & Flow estimated. \\
\hline
\end{tabular}


Tab1e 2,--Sumary of discharge measurements, Navidad River and tributaries, December 14-16, 1970--Continued

\begin{tabular}{|c|c|c|c|c|c|c|c|c|c|}
\hline $\begin{array}{c}\text { Site } \\
\text { no. }\end{array}$ & Date & Stream & Location & $\begin{array}{l}\text { River } \\
\text { mile a/ }\end{array}$ & $\begin{array}{l}\text { Discharge i } \\
\text { Main } \\
\text { stream }\end{array}$ & 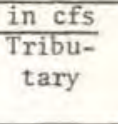 & $\begin{array}{l}\text { Water } \\
\text { temp. } \\
\left({ }^{\circ} \mathrm{C}\right)\end{array}$ & $\begin{array}{l}\text { Specific } \\
\text { conductance } \\
\text { (mi cromhos } \\
\text { at } 25^{\circ} \mathrm{C} \text { ) }\end{array}$ & Remarks \\
\hline & 1970 & & & & & & & & \\
\hline$N-6$ & Dec. 14 & $\begin{array}{l}\text { Ragsdale } \\
\text { Creek }\end{array}$ & $\begin{array}{l}\text { Lat } 29^{\circ} 19^{\prime} 19^{\prime \prime} \text {, long } 96^{\circ} 42^{\prime} 30^{\prime \prime} \text {, just up- } \\
\text { stream from confluence with Navidad } \\
\text { River, } 4.7 \text { miles north of Speaks com- } \\
\text { munity, and } 16.5 \text { miles southeast of } \\
\text { Hallettsville. }\end{array}$ & $\mathrm{b} / 61.8$ & - & 0.08 & $\ldots$ & $\ldots$ & \\
\hline$N-7$ & do & $\begin{array}{l}\text { Navidad } \\
\text { River }\end{array}$ & $\begin{array}{l}\text { Lat } 29^{\circ} 19^{\prime} 18^{\prime \prime} \text {, long } 96^{\circ} 42^{\prime} 30^{\prime \prime} \text {, down- } \\
\text { stream from bridge at Farm Road } 530 \text {, } \\
\text { just downstream from confluence with } \\
\text { Ragsdale Creek, } 4.7 \text { miles north of } \\
\text { Speaks community, and } 16.5 \text { miles south- } \\
\text { east of Hallettsville. }\end{array}$ & 61.8 & 22.8 & $\ldots$ & 14.0 & 862 & \\
\hline $\mathrm{N}-8$ & do & do & $\begin{array}{l}\text { Lat } 29^{\circ} 16^{\prime} 22^{\prime \prime}, \text { long } 96^{\circ} 42^{\prime} 58^{\prime \prime} \text {, just up- } \\
\text { stream from county bridge, } 1.5 \text { miles } \\
\text { northwest of Speaks community, and } \\
\text { about } 18 \text { miles southeast of Halletts- } \\
\text { ville. }\end{array}$ & 57.4 & 21.1 & $\cdots$ & 13,5 & 858 & \\
\hline $\mathrm{N}-9$ & Dec. 15 & $\begin{array}{l}\text { Hardys } \\
\text { Sandy } \\
\text { Creek }\end{array}$ & $\begin{array}{l}\text { Lat } 29^{\circ} 12^{\prime} 38^{\prime \prime}, \text { long } 96^{\circ} 44^{\prime} 32^{\prime \prime}, 0.1 \text { mile } \\
\text { upstream from confluence with Navidad } \\
\text { River, } 4 \text { miles southwest of Speaks } \\
\text { community, and about } 20 \text { miles south- } \\
\text { east of Hallettsville. }\end{array}$ & b/49.9 & $\ldots$ & .07 & + & $\ldots$ & $\begin{array}{l}\text { Shallow sandy } \\
\text { channel. }\end{array}$ \\
\hline$N-10$ & do & $\begin{array}{l}\text { Navidad } \\
\text { River }\end{array}$ & $\begin{array}{l}\text { Lat } 29^{\circ} 11^{\prime} 51^{\prime \prime} \text {, long } 96^{\circ} 44^{\prime} 26^{\prime \prime} \text {, about } 5 \\
\text { miles north of Morales community and } \\
\text { about } 16 \text { miles northwest of Edna. }\end{array}$ & 48.7 & 24.5 & $\ldots$ & 14.0 & 815 & \\
\hline
\end{tabular}

See footnotes at end of table. 
Table 2.--Summary of discharge measurements, Navidad River and tributaries, December 14-16, 1970--Continued

\begin{tabular}{|c|c|c|c|c|c|c|c|c|}
\hline $\begin{array}{l}\text { Site } \\
\text { no. }\end{array}$ & Date & Stream & Location & $\begin{array}{l}\text { River } \\
\text { mile a/ }\end{array}$ & $\begin{array}{l}\text { Discharge in } \\
\text { stream }\end{array}$ & $\begin{array}{l}\text { in cfs } \\
\text { Tribu- } \\
\text { tary }\end{array}$ & $\begin{array}{l}\text { Water } \\
\text { temp. } \\
\left({ }^{\circ} \mathrm{C}\right)\end{array}$ & $\begin{array}{l}\text { Specifi } \\
\text { conducta: } \\
\text { (micromh } \\
\text { at } 25^{\circ} \mathrm{C} \\
\end{array}$ \\
\hline & 1970 & & & & & & & \\
\hline$N-11$ & Dec. 15 & $\begin{array}{l}\text { Navidad } \\
\text { River }\end{array}$ & $\begin{array}{l}\text { Lat } 29^{\circ} 08^{\prime} 07^{\prime \prime}, \text { long } 96^{\circ} 44^{\prime} 38^{\prime \prime}, 10 \mathrm{ft} \text { down- } \\
\text { stream from county bridge, } 1.2 \text { miles } \\
\text { east of Morales community, and } 12.3 \\
\text { miles northwest of Edna. }\end{array}$ & 42.9 & 27.2 & $\cdots$ & 14.0 & 830 \\
\hline $\mathrm{N}-12$ & do & do & $\begin{array}{l}\text { Lat } 29^{\circ} 05^{\prime} 46^{\prime \prime} \text {, long } 96^{\circ} 42^{\prime} 50^{\prime \prime} \text {, at end of } \\
\text { private road leading to gas we } 11,2.0 \\
\text { miles northwest of Mount Olive commun- } \\
\text { ity, and about } 9 \text { miles northeast of } \\
\text { Edna. }\end{array}$ & 39.0 & 26.2 & $\cdots$ & 14.5 & 818 \\
\hline $\mathrm{N}-13$ & do & do & $\begin{array}{l}\text { Lat } 29^{\circ} 03^{\prime} 56^{\prime \prime} \text {, long } 96^{\circ} 40^{\prime} 25^{\prime \prime}, 75 \mathrm{ft} \\
\text { downstream from county bridge, } 1.3 \\
\text { miles east of Mount Olive community, } \\
\text { and } 6.2 \text { miles northwest of Edna. }\end{array}$ & 33.1 & 28.1 & $\cdots$ & 14.5 & 827 \\
\hline$N-14$ & do & do & $\begin{array}{l}\text { Lat } 29^{\circ} 01^{\prime} 52^{\prime \prime}, \text { long } 96^{\circ} 37^{\prime} 14^{\prime \prime}, 100 \mathrm{ft} \\
\text { upstream from Farm Road } 530^{\circ} \text { and about } \\
4 \text { miles northeast of Edna. }\end{array}$ & 27.8 & 29.2 & $\cdots$ & 14.5 & 827 \\
\hline $\mathrm{N}-15$ & Dec. 16 & $\begin{array}{l}\text { Sandy } \\
\text { Creek }\end{array}$ & $\begin{array}{l}\text { Lat } 29^{\circ} 01^{\prime} 39^{\prime \prime}, \text { long } 96^{\circ} 33^{\prime} 14^{\prime \prime}, 200 \mathrm{ft} \\
\text { upstream from confluence with Navidad } \\
\text { River and } 2.6 \text { miles southwest of } \\
\text { Ganado. }\end{array}$ & $\mathrm{b} / 22.1$ & - & 0.43 & - & $\cdots$ \\
\hline$N-16$ & do & $\begin{array}{l}\text { Navidad } \\
\text { River }\end{array}$ & $\begin{array}{l}\text { Lat } 29^{\circ} 01^{\prime} 35^{\prime \prime} \text {, long } 96^{\circ} 33^{\prime} 09^{\prime \prime}, 400 \mathrm{ft} \\
\text { upstream from U.S. Highway } 59 \text { and } 2.6 \\
\text { miles southwest of Ganado. }\end{array}$ & 22.0 & 29.1 & $\cdots$ & $\cdots$ & 806 \\
\hline
\end{tabular}


The mineralization of the water in the Navidad River decreases slightly from the upper end of the reach to the lower end (fig. 13). Within the $64.4 \mathrm{mile}$ reach, the specific conductance decreased from 855 micromhos at $25^{\circ} \mathrm{C}$ at site $\mathrm{N}-1$ to 792 micromhos at $25^{\circ} \mathrm{C}$ at site $\mathrm{N}-18$.

\section{Lavaca River}

The low-flow investigation of the Lavaca River was made from the crossing on U.S. Highway $90 \mathrm{~A}$ at Hallettsville to the crossing on a county road 4.1 miles south of Edna, a distance of 65.4 river miles. The lower end of the reach is 12.3 miles upstream from the railroad bridge at the junction of the Lavaca and Navidad Rivers.

In almost all of the reach in Jackson County, the main stem of the Lavaca River flows in a bed of flood-plain alluvium. In most of the reach in Lavaca County, the stream is embedded in isolated patches of flood-plain alluvium and in the Fleming Formation, Goliad Sand, Bentley Formation, and Montgomery Formation (fig. 2).

The investigation showed that the Lavaca River had mostly moderate to large gains in flow and one moderate loss (table 3). Within the 65.4mile reach of the channel, streamflow increased from 4.21 cfs at the upper end (site L-1) to $37.3 \mathrm{cfs}$ at the lower end (si.te L-18). This is an increase in flow of almost 800 percent and an average increase in flow per channel mile of $0.5 \mathrm{cfs}$. Rocky Creek, which had a flow of $12.6 \mathrm{cfs}$, was the largest contributor of water to the main stem of the Lavaca River and accounted for 85 percent of tributary inflow.

With the exception of the one moderate loss in streamflow and the large gain in inflow from Rocky Creek, the rate of increase in flow between the upper and lower ends of the reach, though fairly uniform, was slightly greater in about the lower four-fifths of the reach than in the upper one-fifth (fig. 14). This slightly greater rate of gain in the lower four-fifths of the reach is attributed to a greater transmissivity of the water-bearing formations adjacent to the stream.

The moderate loss in streamflow between miles 57.5 and 49.3 may be due to a lower altitude of the water table at places within this reach, but this condition was not confirmed by test drilling. Part of the indicated loss may be accounted for by possible measurement error.

The mineralization of the water in the Lavaca River decreases slightly from the upper end of the reach to the lower end. Within the 65.4-mile reach, the specific conductance decreased from 878 micromhos at $25^{\circ} \mathrm{C}$ at site $\mathrm{L}-1$ to 815 micromhos at $25^{\circ} \mathrm{C}$ at site $\mathrm{L}-18$. 


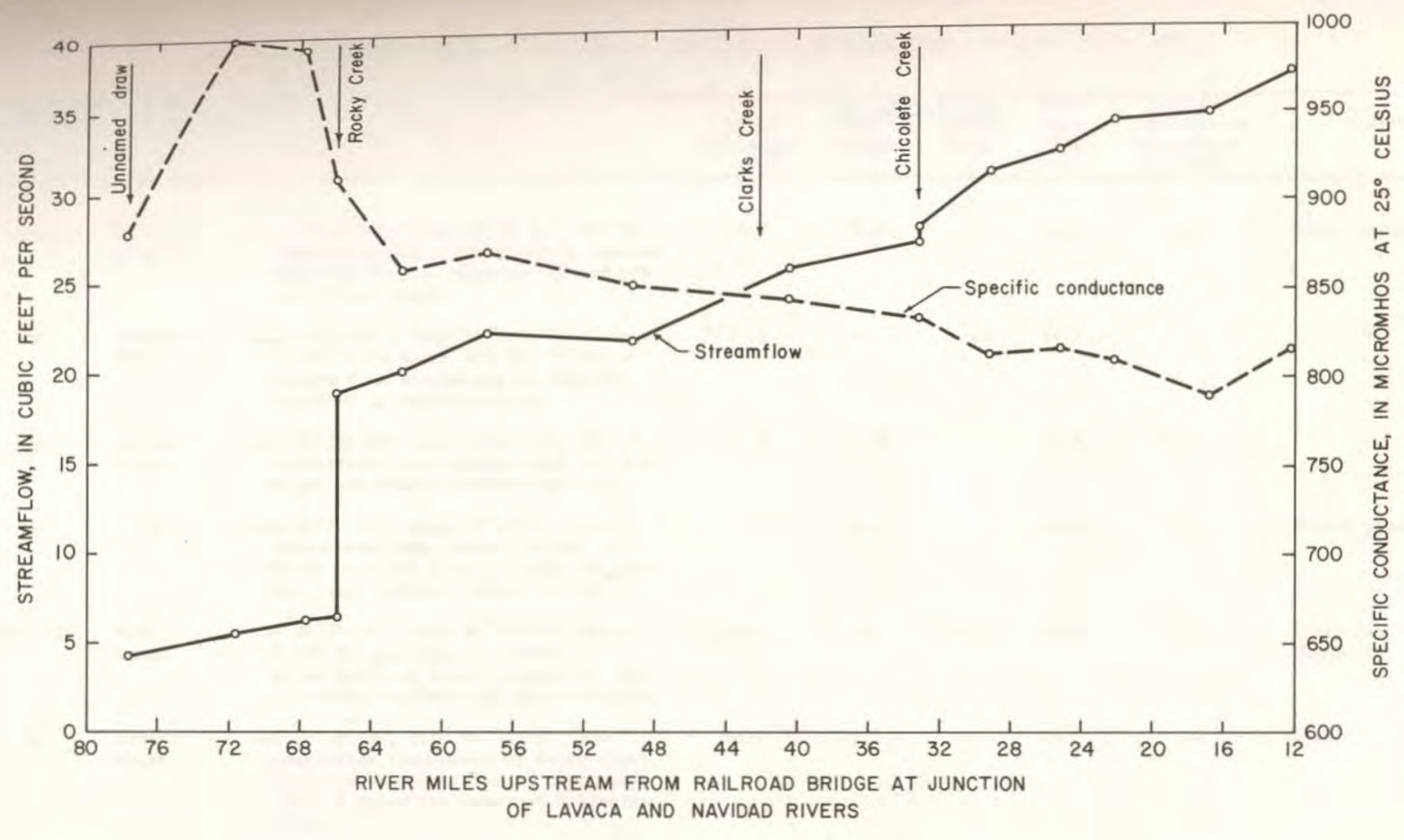

FIGURE 14.-Streamflow and specific conductance of water, Lavaca River, December 14-17, 1970 
Table 3.--Summary of discharge measurements, Lavaca River and tributaries, December 14-17, 1970

\begin{tabular}{|c|c|c|c|c|c|c|c|c|c|}
\hline $\begin{array}{l}\text { Site } \\
\text { no. }\end{array}$ & Date & Stream & Location & $\begin{array}{l}\text { River } \\
\text { mile a/ }\end{array}$ & $\begin{array}{l}\frac{\text { Discharge }}{\text { Main }} \\
\text { stream }\end{array}$ & 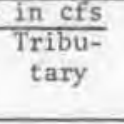 & $\begin{array}{l}\text { Water } \\
\text { temp. } \\
\left({ }^{\circ} \mathrm{C}\right)\end{array}$ & $\begin{array}{l}\text { Specific } \\
\text { conductance } \\
\text { (micromhos } \\
\text { at } 25^{\circ} \mathrm{C} \text { ) }\end{array}$ & Remarks \\
\hline & 1970 & & & & & & & & \\
\hline $\mathrm{L}-1$ & Dec. 14 & $\begin{array}{l}\text { Lavaca } \\
\text { River }\end{array}$ & $\begin{array}{l}\text { Lat } 29^{\circ} 26^{\prime} 34^{\prime \prime}, \text { long } 96^{\circ} 54^{\prime} 41^{\prime \prime}, 200 \mathrm{ft} \\
\text { downstream from stream-gaging station } \\
08163500 \text { at U.S. Highways } 77^{\circ} \text { and } 90 \mathrm{~A} \\
\text { at Hallettsville. }\end{array}$ & 77.7 & 4.21 & $\cdots$ & 14.5 & 878 & Sandy channe1. \\
\hline $\mathrm{L}-2$ & do & $\begin{array}{l}\text { Unnamed } \\
\text { draw }\end{array}$ & $\begin{array}{l}\text { Lat } 29^{\circ} 26^{\prime} 32^{\prime \prime} \text {, long } 96^{\circ} 56^{\prime} 39^{\prime \prime}, 10 \mathrm{ft} \text { up- } \\
\text { stream from mouth and } 250 \mathrm{ft} \text { down- } \\
\text { stream from stream-gaging station } \\
08163500 \text { at Hallettsville. }\end{array}$ & $\mathrm{b} / 77.6$ & - & 0.23 & 25.5 & $\cdots$ & do \\
\hline$L-3$ & do & $\begin{array}{l}\text { Lavaca } \\
\text { River }\end{array}$ & $\begin{array}{l}\text { Lat } 29^{\circ} 23^{\prime} 02^{\prime \prime}, \text { long } 96^{\circ} 54^{\prime} 52^{\prime \prime}, 100 \mathrm{ft} \\
\text { downstream from unnamed draw and } 4.4 \\
\text { miles southeast of Hallettsville. }\end{array}$ & 71.8 & 5.40 & $\cdots$ & 15.0 & 1,000 & do \\
\hline$L-4$ & do & do & $\begin{array}{l}\text { Lat } 29^{\circ} 21^{\prime} 11^{\prime \prime} \text {, long } 96^{\circ} 54^{\prime} 50^{\prime \prime}, 100 \mathrm{ft} \\
\text { downstream from county bridge, } 4.7 \\
\text { miles north of Ezzell community, and } \\
6.5 \text { miles south of Hallettsville. }\end{array}$ & 67.7 & 6.27 & - & 14.5 & 991 & Smooth channel. \\
\hline$L-5$ & Dec. 15 & $\begin{array}{l}\text { Rocky } \\
\text { Creek }\end{array}$ & $\begin{array}{l}\text { Lat } 29^{\circ} 20^{\prime} 19^{\prime \prime}, \text { long } 96^{\circ} 54^{\prime} 35^{\prime \prime} \text {, about } \\
1,000 \mathrm{ft} \text { upstream from mouth, } 3.9 \\
\text { miles north of Ezze11 community, and } \\
7.4 \text { miles southeast of Hallettsville, }\end{array}$ & $\mathrm{b} / 66.0$ & $\cdots$ & 12.6 & 14.0 & 803 & $\begin{array}{l}\text { Irregular sandy } \\
\text { channel. }\end{array}$ \\
\hline$L-6$ & do & $\begin{array}{l}\text { Lavaca } \\
\text { River }\end{array}$ & $\begin{array}{l}\text { Lat } 29^{\circ} 20^{\prime} 13^{\prime \prime} \text {, long } 96^{\circ} 54^{\prime} 25^{\prime \prime}, 300 \mathrm{ft} \\
\text { downstream from mouth of Rocky Creek, } \\
3.7 \text { miles north of Ezze11 community, } \\
\text { and } 7.5 \text { miles southeast of Halletts- } \\
\text { ville. }\end{array}$ & 66.0 & 19.0 & $\cdots$ & 14.0 & 910 & Sandy channel. \\
\hline
\end{tabular}

See footnotes at end of table. 

Table 3.--Summary of discharge measurements, Lavaca River and tributaries, December 14-17, 1970--Concluded

\begin{tabular}{|c|c|c|c|c|c|c|c|c|c|}
\hline $\begin{array}{c}\text { Site } \\
\text { no. }\end{array}$ & Date & Stream & Location & $\begin{array}{c}\text { River } \\
\text { mile a/ }\end{array}$ & $\begin{array}{l}\frac{\text { Discharge }}{\text { Main }} \\
\text { stream }\end{array}$ & $\begin{array}{l}\text { in cfs } \\
\text { Tribu- } \\
\text { tary }\end{array}$ & $\begin{array}{l}\text { Water } \\
\text { temp. } \\
\left({ }^{\circ} \mathrm{C}\right)\end{array}$ & $\begin{array}{l}\text { Specific } \\
\text { conductance } \\
\text { (micromhos } \\
\text { at } 25^{\circ} \mathrm{C} \text { ) }\end{array}$ & Remarks \\
\hline & 1970 & & & & & & & & \\
\hline$L-13$ & Dec, 16 & $\begin{array}{l}\text { Lavaca } \\
\text { River }\end{array}$ & $\begin{array}{l}\text { Lat } 29^{\circ} 05^{\prime} 04^{\prime \prime}, \text { long } 96^{\circ} 49^{\prime} 02^{\prime \prime}, 100 \mathrm{ft} \\
\text { downstream from mouth of Chicolete } \\
\text { Creek and } 12.6 \text { miles northwest of Edna. }\end{array}$ & 33.3 & 28.3 & -. & 16.5 & 832 & $\begin{array}{l}\text { Flat, firm, } \\
\text { sandy channel. }\end{array}$ \\
\hline $\mathrm{L}-14$ & do & do & $\begin{array}{l}\text { Lat } 29^{\circ} 03^{\prime} 33^{\prime \prime}, \text { long } 96^{\circ} 46^{\prime} 39^{\prime \prime}, 150 \mathrm{ft} \\
\text { upstream from county bridge and } 9.6 \\
\text { miles northwest of Edna. }\end{array}$ & 29.2 & 31.5 & -. & 15.0 & 812 & Sandy channel. \\
\hline $\mathrm{L}-15$ & Dec. 17 & do & $\begin{array}{l}\text { Lat } 29^{\circ} 02^{\prime} 31^{\prime \prime}, \text { long } 96^{\circ} 43^{\prime} 48^{\prime \prime} \text {, near } \\
\text { Laughter Cemetery and } 6.6 \text { miles north- } \\
\text { west of Edna. }\end{array}$ & 25.3 & 32,7 & $\cdots$ & 12.0 & 815 & do \\
\hline $\mathrm{L}-16$ & do & do & $\begin{array}{l}\text { Lat } 29^{\circ} 00^{\prime} 44^{\prime \prime}, \text { long } 96^{\circ} 42,22^{\prime \prime}, 0.6 \text { mile } \\
\text { northwest of Lost Bridge Road and } 4.3 \\
\text { miles northwest of Edna. }\end{array}$ & 22,2 & 34.4 & -. & 19.0 & 809 & do \\
\hline $\mathrm{L}-17$ & Dec. 16 & do & $\begin{array}{l}\text { Lat } 28^{\circ} 57^{\prime} 34^{\prime \prime} \text {, long } 96^{\circ} 41 ' 10^{\prime \prime} \text {, about } \\
300 \mathrm{ft} \text { upstream from U.S. Highway } 59 \\
\text { and } 2.7 \text { miles southeast of Edna. }\end{array}$ & 16.8 & 34.9 & $\cdots$ & 15.5 & 789 & $\begin{array}{l}\text { Smooth sandy } \\
\text { channel. }\end{array}$ \\
\hline $\mathrm{L}-18$ & do & do & $\begin{array}{l}\text { Lat } 28^{\circ} 55^{\prime} 09^{\prime \prime}, \text { long } 96^{\circ} 39^{\prime} 44^{\prime \prime} \text {, at bridge } \\
\text { leading to Camp Independence and } 4.1 \\
\text { miles southeast of Edna. }\end{array}$ & 12.3 & 37.3 & -- & 15.5 & 815 & do \\
\hline
\end{tabular}

a/ River miles measured from railroad bridge at junction of Lavaca and Navidad Rivers. b/ River mile at mouth of tributary. 


\section{LAND-SURFACE SUBSIDENCE}

\section{Causes and Evidence of Subsidence}

The principal cause of land-surface subsidence in this area is the withdrawal of large quantities of ground water for rice irrigation from a heavily pumped artesian zone. This zone, from 250 to 600 feet thick, is between 100 and 350 feet below land surface in some areas, and between 200 and 800 feet below land surface in other areas. The deposits that are affected by the heavy pumpage are several hundred feet of unconsolidated sediments of Tertiary and Quaternary age that form parts of the Chicot and Evangeline aquifers.

Conclusive evidence from studies in the Houston area (Winslow and Wood, 1959; and Gabrysch, 1969) and in California and other western states (Poland, 1972), illustrates that a decrease in artesian pressure by large withdrawals of ground water creates stresses in the aquifer that compact the sediments and results in subsidence.

In Jackson County, the pumping of large quantities of water decreased the artesian pressure, which provided a buoyant effect that helped to support the weight of the overburden. The resulting stress on the aquifer caused water to move slowly out of the water-saturated clays into the sands. The clays, which are highly compressible, became increasingly compacted, which in turn, produced the subsidence.

Subsidence in the area is indicated by the releveling of selected bench marks by the National Ocean Survey (formerly the U.S. Coast and Geodetic Survey). Some of these bench marks were established as early as 1918 and have been releveled at various times since then. Others were established at later dates and releveled less frequently. The latest releveling was in the early part of 1972 . The results of the most recent releveling indicate that the land surface has subsided about 1 foot or slightly less in the Lolita and La Ward areas and about 0.75 foot in the Cordele area. Subsidence in many other parts of Jackson County is less than 0.5 foot.

\section{Rate and Extent of Subsidence}

The rate of land-surface subsidence depends upon a number of factors, chiefly the rate of water-level decline (artesian pressure), and the total thickness of the clay beds that are affected by the decline. The correlation between land-surface subsidence and water-level declines in Jackson County is shown on figure 15 by the graphs of subsidence of individual bench marks and the decline of water levels in nearby wells. 

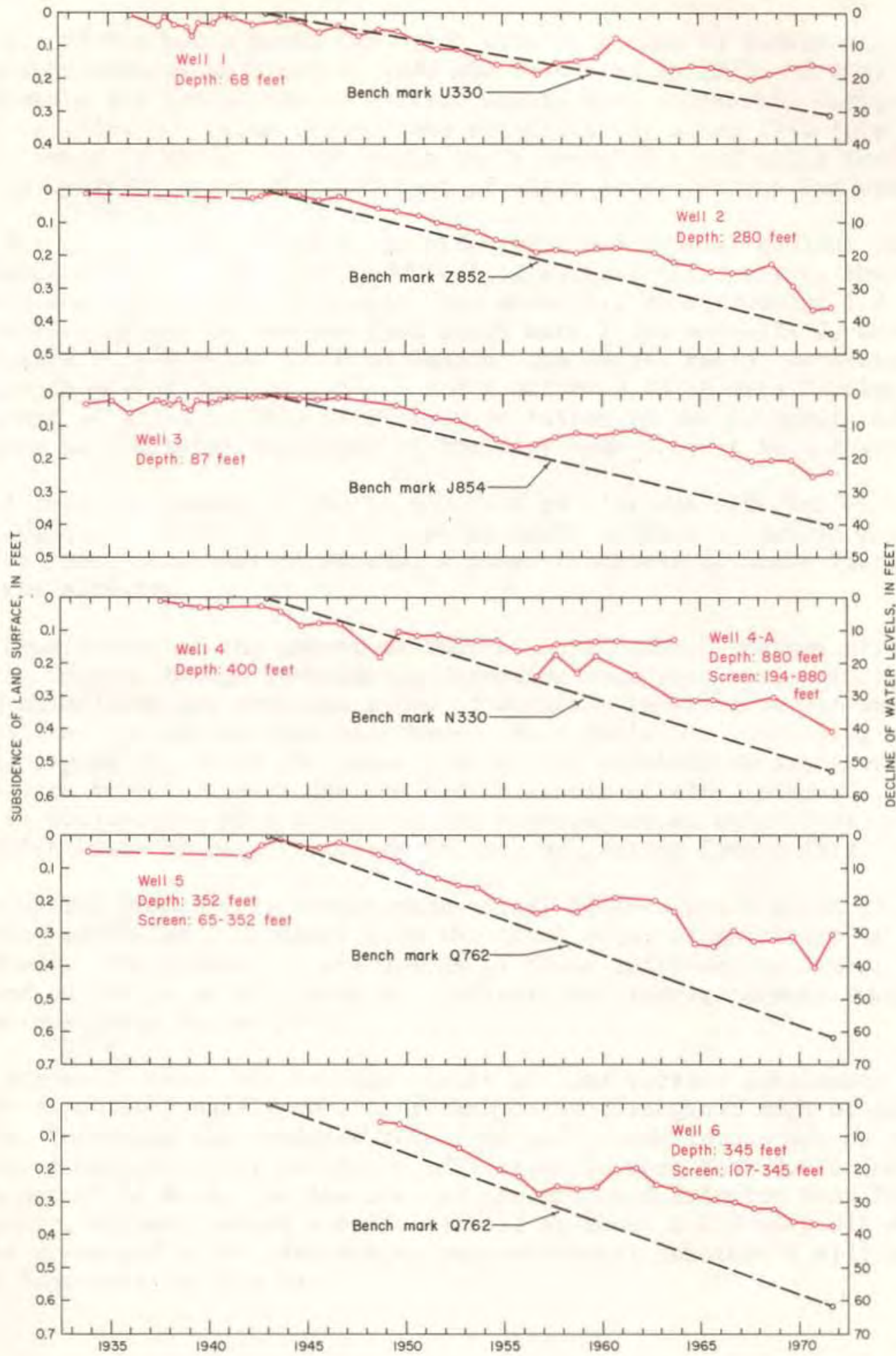
All of the bench marks for which data were used in construction of the graphs were established in 1943 and releveled in 1972. Ground-water withdrawals for irrigation in Jackson County were relatively insignificant prior to 1943, but began to increase significantly after 1943 (fig. 16). Water levels in wells did not begin their downward trend until the early 1940 's; by 1972, about 20 to 40 feet of water-level decline had occurred.

The ratio of land-surface subsidence to water-level decline varies in Jackson County. For every 100 feet of water-level decline, the amount of land-surface subsidence ranges from about 1.2 feet to about 1.7 feet. The smaller ratio, determined from bench mark $Z 852$ and well 2, occurred in an area 5 to 6 miles north of Ganado; the larger ratio, determined from bench mark Q 762 and we11s 5 and 6 occurred in an area 7 miles southsoutheast of Ganado. This difference in ratios is due primarily to differences in the total thickness of the clay beds subject to compaction.

A total thickness of 350 to 450 feet of clay was affected by waterlevel declines in the area 5 to 6 miles north of Ganado, but in the area 7 miles south-southeast of Ganado, a total thickness of about 750 feet of clay was affected.

Predictions of the amount of future subsidence in various areas of Jackson County, though necessarily depending upon some assumptions, are based chiefly on the previous rates of declines in water levels and on the thicknesses of the clay interbeds. As a basis for predicting subsidence, figure 17, which graphically shows the relation of land-surface subsidence to water-level decline and thickness of clay interbeds, was used in conjunction with a map showing average annual water-level declines and thicknesses of clay interbeds in much of Jackson County (fig. 18).

Control points were established mainly by the intersection of lines of equal water-level declines with the lines of equal thickness of clay interbeds. The product of the values of these intersecting lines, when plotted on the graph in figure 17, indicate the average annual subsidence at various sites in the area.

Figure 19 shows the average amount of land-surface subsidence that may be expected annually on a long-term basis throughout much of Jackson County, including the proposed reservoir area. Subsidence may be expected to vary from 0.012 foot southwest of Morales to more than 0.026 foot northeast of La Ward. In the area of the proposed Palmetto Bend Dam and Reservoir, minimum annual subsidence will be about 0.013 to 0.015 foot at the upper end of the reservoir; maximum annual subsidence will be about 0.019 foot near the dam site. 


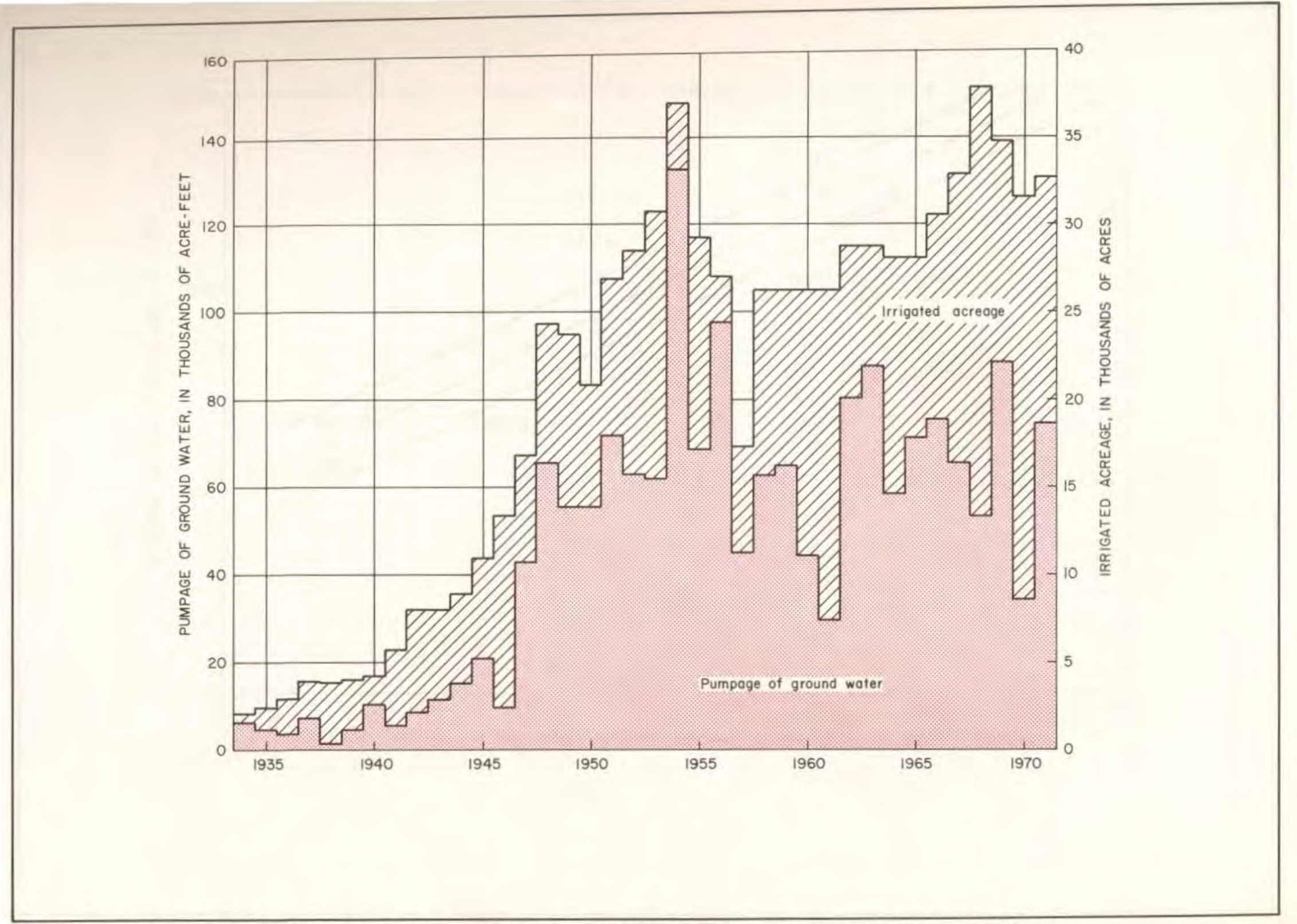




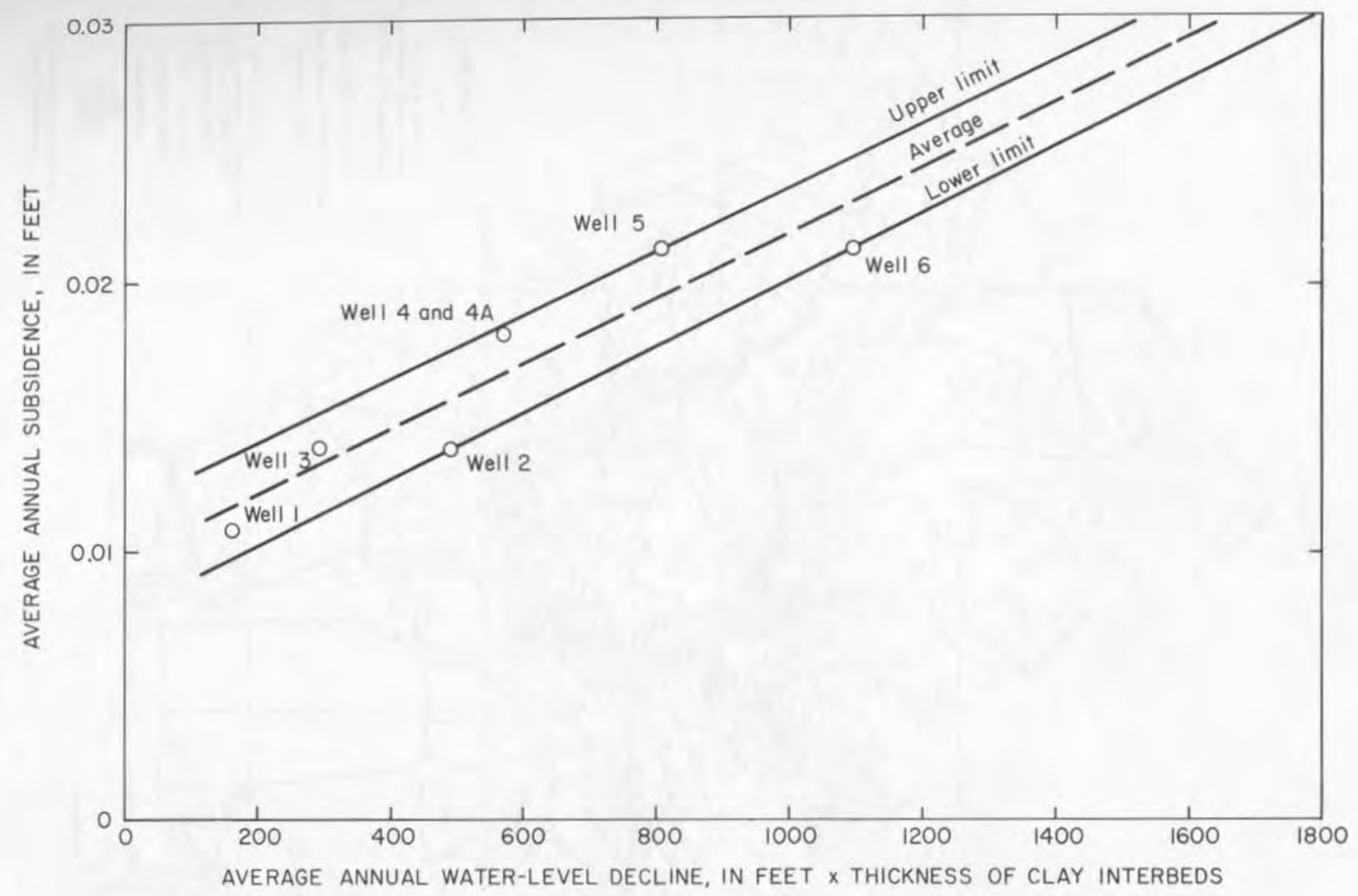

FIGURE 17.- Relation of subsidence to water-level decline (1943-72) and thickness of clay interbeds 


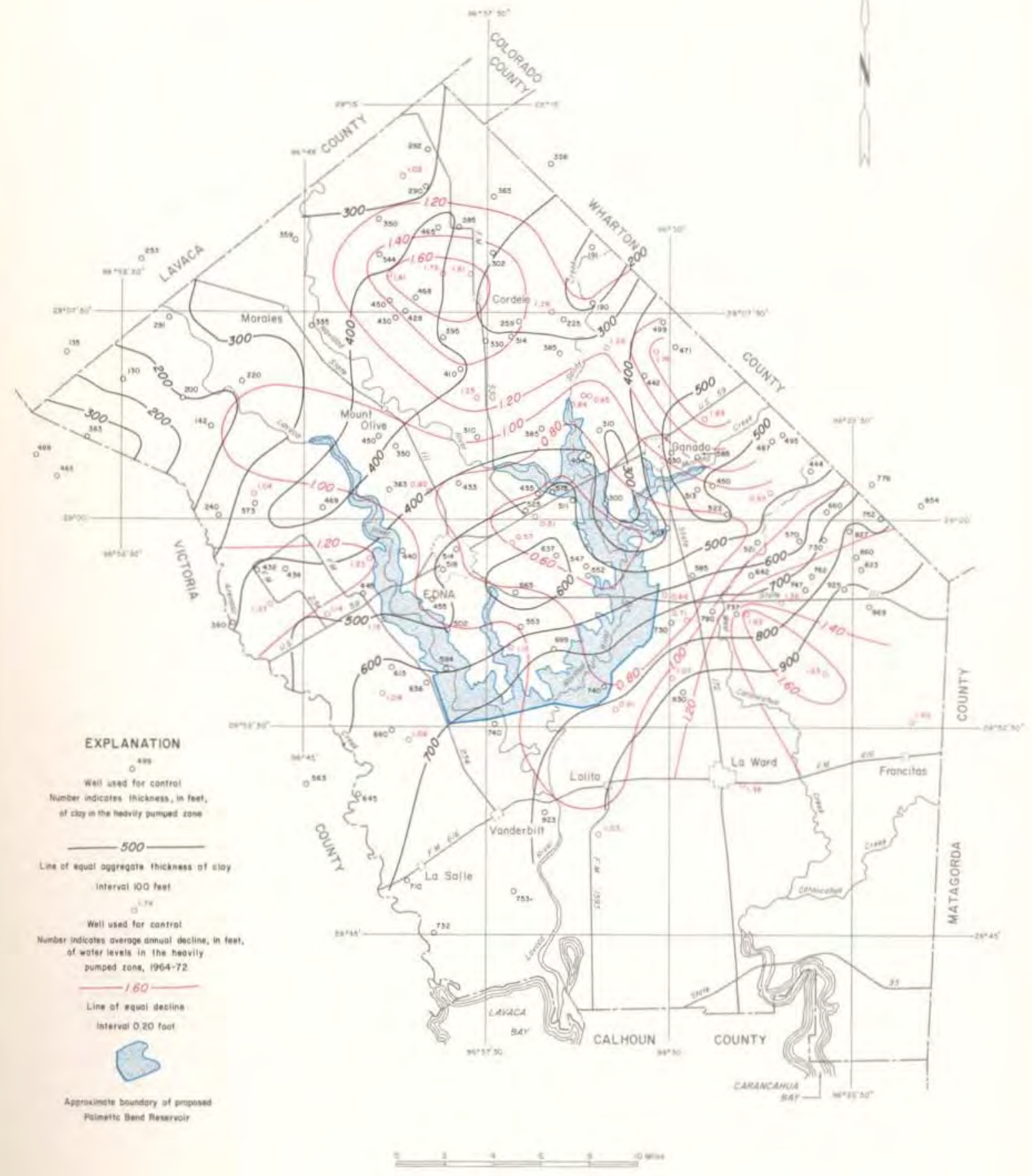




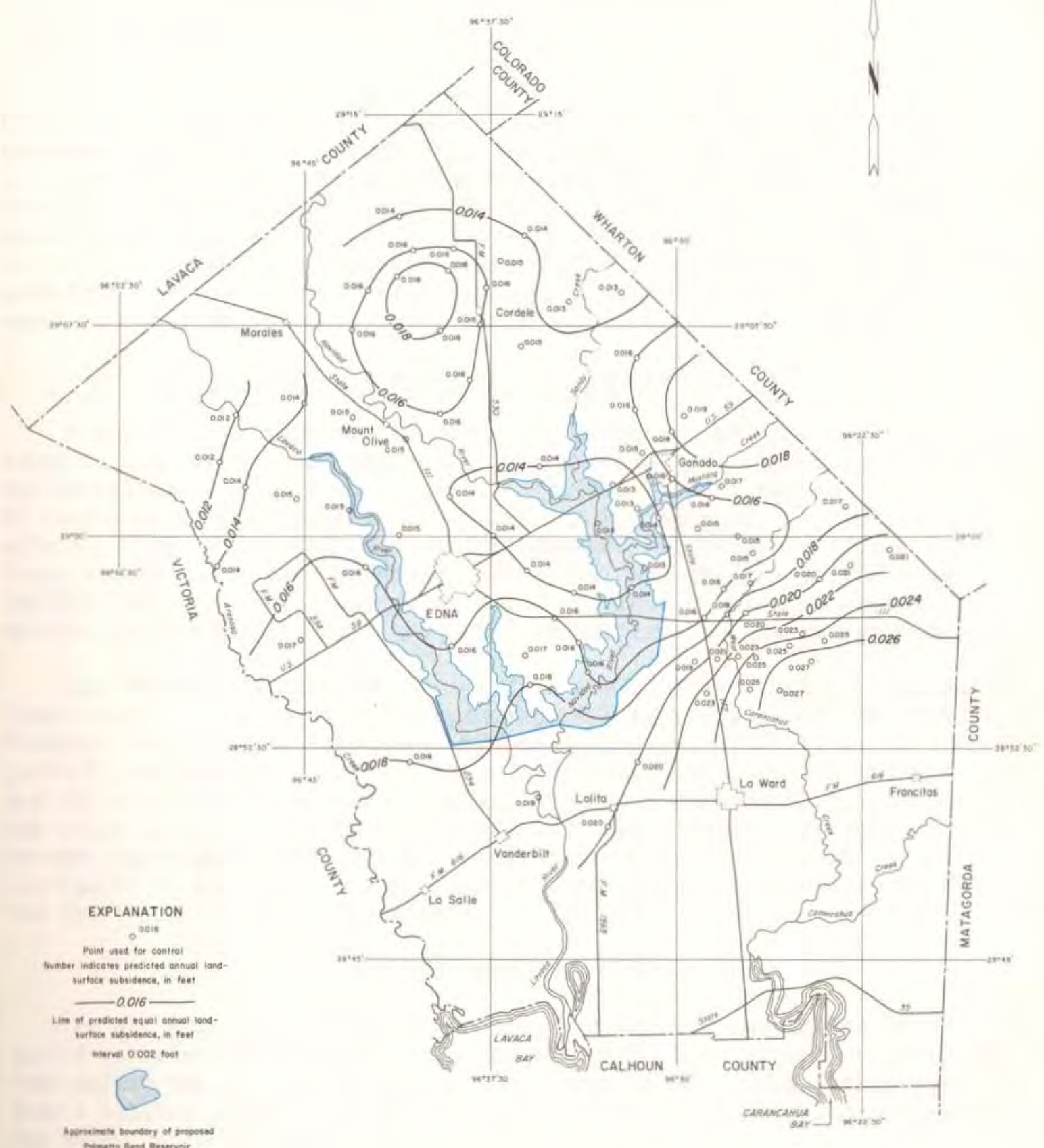

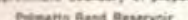


The validity of the predicted rate of subsidence depends mainly on the assumption that ground-water withdrawals and water-level declines in Jackson County will continue at about the current (1972) rate. Because ground-water withdrawals for rice irrigation accounts for more than 90 percent of the ground water used in Jackson County, any significant change in the amount of irrigated acreage will in turn affect the rate of waterlevel decline.

The amount of irrigated acreage, which has been controlled since 1950 by U.S. Government allotments, usually has varied annually and has increased slightly since 1965 (fig. 16); but ground-water pumpage has not yet increased in proportion to the increase in irrigated acreage because of above normal rainfall during the irrigation season. Nevertheless, water levels are expected to continue to decline because future pumpage in Jackson County probably will exceed, at times, the 1963 draft of 92,000 acre-feet per year for all types of use--a rate that is approximately equal to the rate of recharge to the aquifer (Baker, 1965, p. 80).

\section{Structural Effects of Subsidence}

The fairly uniform distribution of irrigation wells in Jackson County tends to distribute the subsidence over a large area, thereby minimizing the undesirable effects that usually accrue from differential subsidence by concentrated pumpage from small areas. No undesirable structural effects, such as cracked foundations, damaged highways, or broken pipelines are known to have occurred. Some regional changes in the slope of the land surface have occurred and will continue to occur. This will affect, in varying degrees, the drainage patterns and stream gradients.

The faults that have been mapped in the southern half of Jackson County and surrounding areas, including much of the area of the proposed Palmetto Bend Dam and Reservoir are shown on figure 20. Most of the faults probably are inactive, but because of the large ground-water withdrawals and the attendant 1and-surface subsidence, some additional displacenents may occur along some of the fault planes. These faults probably do not present any significant hazards, but construction design that would avoid the faults or would allow for displacements that probably will not exceed the total subsidence would minimize any hazard.

\section{SUMMARY AND CONCLUSIONS}

At all nine monitoring sites along the Navidad and Lavaca Rivers, ground water was discharging into the streams. This situation prevailed even during the irrigation season when large ground-water withdrawals from a heavily pumped zone of the aquifer normally lowers the altitude of the water table at many places. 


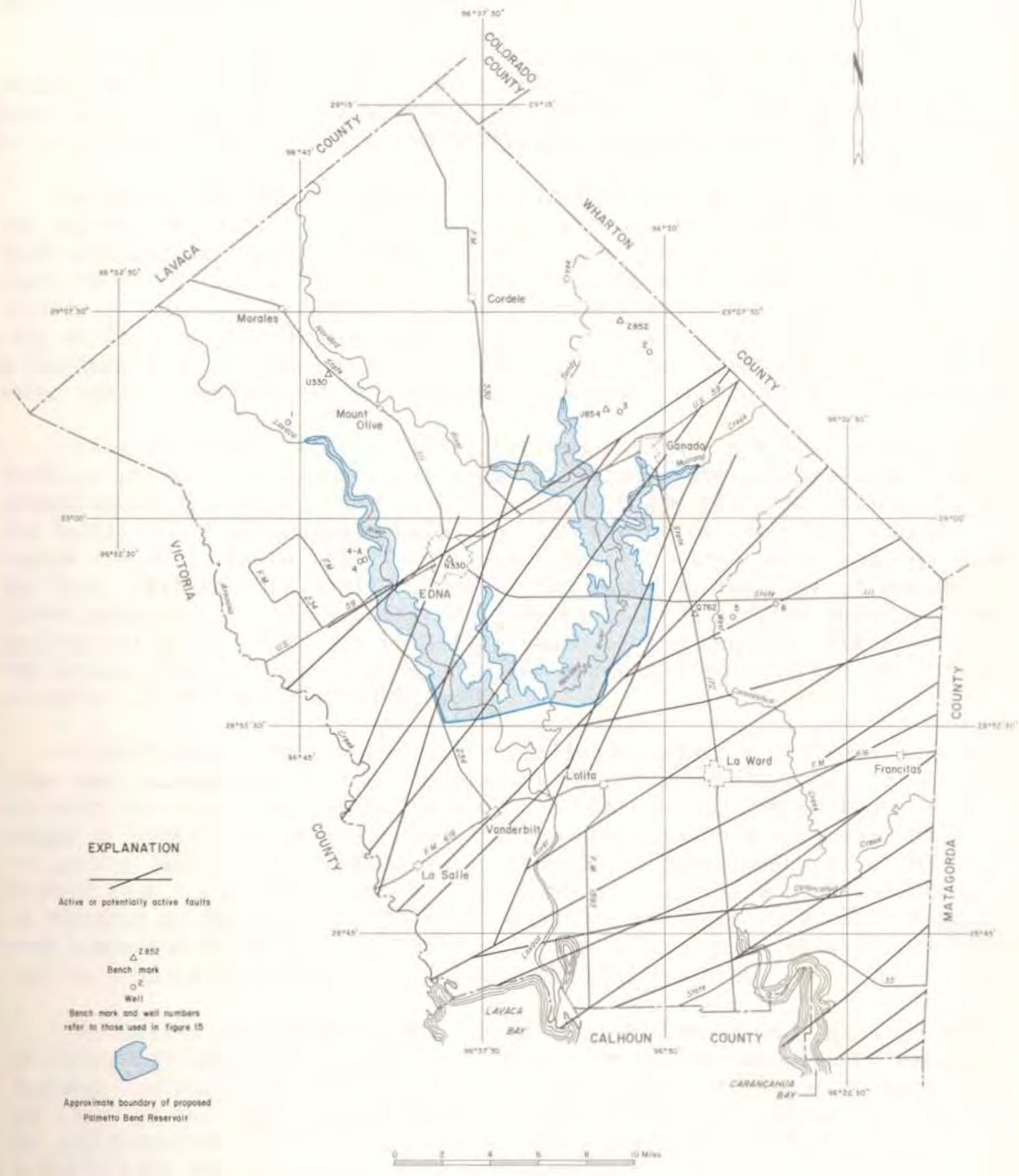


At most of the monitoring sites, the area contributing ground water to the streams is relatively wide, extending at least as far back from the streams as the most distant test wells. At a few of the monitoring sites, only a relatively narrow area adjacent to the streams contributed groundwater effluent because the shallow water levels at greater distances from the streams were lower than stream level.

A few shallow observation wells with more than 30 years of record indicate that the water levels are continuing to decline, though in some years of above normal rainfall the rate of decline is sharply less; and in other wet years, even a brief recovery of water levels has been recorded.

Long-term records of water-level fluctuations are not available for the narrow area adjacent to the streams, but short-term records indicate that significant rises in water levels result from heavy rainfall and from flooding in the stream valleys. These periodic additions of water to storage in the aquifer adjacent to the streams tend to insure seepage outflow during the intervening periods of below normal rainfall. Even though a complete loss of the low flow of the streams by infiltration to a lowered water table seems remote, a reduction in streamflow probably has occurred.

Low-flow investigations of the Navidad and Lavaca Rivers support the findings at the monitoring sites that the streams are gaining flow from ground-water discharge. The investigations showed that the Navidad River had mostly small to moderate gains in flow and a few small to moderate losses and that the Lavaca River had moderate to large gains and one moderate loss. Within a 64.4-mile reach of the channel, the flow of the Navidad River increased by 65 percent from $18.8 \mathrm{cfs}$ to $31.0 \mathrm{cfs}$, or about $0.2 \mathrm{cfs}$ per channel mile. Within a $65.4-$ mile reach of the channel, the flow of the Lavaca River increased by almost 800 percent from $4.21 \mathrm{cfs}$ to $37.3 \mathrm{cfs}$, or about 0.5 cfs per channel mile.

Predictions of the amount of future land-surface subsidence depend upon some assumptions, but are based chiefly on previous rates of declines in water levels and on thicknesses of clay interbeds. On this basis, the amount of subsidence that may be expected annually on a long-term basis in much of Jackson County will range from 0.012 foot southwest of Morales to more than 0.026 foot northeast of La Ward. Average annual subsidence in the area of the proposed Palmetto Bend Dam and Reservoir will range from a minimum of about 0.013 to 0.015 foot at the upper ends of the reservoir to a maximum of about 0.019 foot near the dam site.

The fairly uniform distribution of the subsidence over a large area minimizes any undesirable effects such as structural failures of manmade features. Structural failures have not occurred, but regional changes in the slope of the land surface have occurred and will continue to occur. Any additional vertical displacements along the existing fault planes probably will not exceed the total subsidence. 
Baker, E. T., Jr., 1965, Ground-water resources of Jacks on County, Texas: Texas Water Deve1. Board Rept. 1, 225 p.

Bernard, H. A., LeBlanc, R. J., and Major, C. F., 1962, Recent and Pleistocene geology of southeast Texas, Field excursion no. 3, in Geology of the Gulf Coast and central Texas and guidebook of excursions, Geol. Soc, America, 1962 Ann. Mtg.: Houston, Texas, Houston Geol. Soc., p. 175-224.

Doering, John, 1956, Quaternary surface, Gulf Coast: Am. Assoc. Petroleum Geologists Bull., v. 40, no. 8, p. 1816-1862.

Eargle, D. H., Hinds, G. W., and Weeks, A. M. D., 1971, Uranium geology and mines, south Texas: University of Texas, Bureau of Economic Geology Gui debook 12, 59 p.

Fisher, W. L., and others, 1972, Environmental geologic atlas of the Texas coastal zone-Galveston-Houston area: University of Texas, Bureau of Economic Geology Atlas.

Gabrysch, R, K., 1969, Land-surface subsidence in the Houston-Galveston region, Texas, in Land subsidence, Tokyo Symposium: Internat. Assoc. Sci. Hydrology Pub., v. 1, no. 88, p. 43-54, 1971.

Hubbert, M. K., 1940, The theory of ground-water motion: Jour. Geology, v. 48 , no. 8 , pt. 1 , p. $785-944$.

Lohman, S. W., 1972, Ground-water hydraulics: U.S. Geol. Survey Prof. Paper $708,70 \mathrm{p}$.

Plummer, F. B., 1932, Cenozoic systems in Texas, in The geology of Texas, v, 1, Stratigraphy: University of Texas Buli. 3232, p. 519-818.

Poland, J. F., 1972, Land subsidence in the western states due to groundwater overdraft: Water Resources Bu11., v. 8, no. 1, p. 118-131.

University of Texas, Bureau of Economic Geology, 1968a, Geologic atlas of Texas, Beaumont sheet-Harold Norman Fisk Memorial Edition: Austin, Texas, University of Texas, Bureau of Economic Geology, scale 1:250,000.

1968b, Geologic atlas of Texas, Houston sheet-Paul Weaver Memorial Edition: Austin, Texas, University of Texas, Bureau of Economic Geology, scale $1: 250,000$. 


\section{REFERENCES CITED--Concluded}

Weaver, Paul, and Sheets, M. M., 1962, Active faults subsidence, and foundation problems in the Houston, Texas, area, Field excursion no. 5, in Geology of the Gulf Coast and central Texas and guidebook of excursions, Geol. Soc. America, 1962 Ann. Mtg.: Houston, Texas, Houston Geo1. Soc., p. 254-265.

Winslow, A. G., and Wood, L. A., 1959, Relation of land subsidence to ground-water withdrawals in the upper Gulf Coast region, Texas: Min. Eng., no. 10, p. 1030-1034, Am. Inst. Mining Meta11. and Petroleum Engineers Trans., v. 214. 
Table 4.--Records of wells at monitoring sites

\begin{tabular}{|c|c|c|c|c|c|}
\hline \multirow{2}{*}{$\begin{array}{c}\text { We11 } \\
\text { number }\end{array}$} & \multirow{2}{*}{$\begin{array}{c}\text { Date } \\
\text { drilled }\end{array}$} & \multirow{2}{*}{$\begin{array}{l}\text { Depth of } \\
\text { wel1 } \\
\text { (ft.) }\end{array}$} & \multicolumn{2}{|c|}{ Casing } & \multirow{2}{*}{$\begin{array}{c}\text { Screened } \\
\text { interval } \\
\text { (ft.) }\end{array}$} \\
\hline & & & $\begin{array}{c}\text { Diameter } \\
\text { (in.) }\end{array}$ & $\begin{array}{l}\text { Depth } \\
\text { (ft.) }\end{array}$ & \\
\hline
\end{tabular}

Navidad River Monitoring Site 1

$\begin{array}{lcllll}1 & \text { Sept. } 1970 & 29 & 1 & 19 & 19-29 \\ 2 & \text { do } & 63.2 & 1 & 53.2 & 53.2-63.2 \\ 3 & \text { do } & 56.5 & 1 & 46.5 & 46.5-56.5\end{array}$

Navidad River Monitoring Site 2

$\begin{array}{lcl}1 & \text { Sept. } 1970 & 42.3 \\ 2 & \text { do } & 50.6 \\ 3 & \text { do } & 48.5\end{array}$

$\begin{array}{ll}1 & 32.3 \\ 1 & 40.6 \\ 1 & 38.5\end{array}$

$32.3-42.3$ 40.6-50.6 $38.5-48.5$

Navidad River Monitoring Site 3

$\begin{array}{cllll}\text { Sept. } 1970 & 24 & 1 & 14 & 14-24 \\ \text { do } & 38 & 1 & 28 & 28-38 \\ \text { do } & 42 & 1 & 32 & 32-42\end{array}$

Navidad River Monitoring Site 4

$\begin{array}{llllll}1 & \text { Oct. } 1970 & 44.4 & 1 & 34.4 & 34.4-44.4 \\ 2 & \text { do } & 60.6 & 1 & 50.6 & 50.6-60.6 \\ 3 & \text { do } & 52.5 & 1 & 42.5 & 42.5-52.5\end{array}$

Navidad River Monitoring Site 5

$\begin{array}{cllll}\text { Sept. } 1970 & 30.7 & 1 & 20.7 & 20.7-30.7 \\ \text { do } & 34.5 & 1 & 24.5 & 24.5-34.5 \\ \text { do } & 66.8 & 1 & 56.8 & 56.8-66.8\end{array}$

Navidad River Monitoring Site 6

$\begin{array}{llllll}1 & \text { Oct. } 1970 & 27.8 & 1 & 17.8 & 17.8-27.8 \\ 2 & \text { do } & 29.5 & 1 & 19.5 & 19.5-29.5 \\ 3 & \text { do } & 41.2 & 1 & 31.2 & 31.2-41.2\end{array}$

Navidad River Monitoring Site 7

$\begin{array}{lcllll}1 & \text { Oct. } 1970 & 47.6 & 1 & 37.6 & 37.6-47.6 \\ 2 & \text { do } & 37.6 & 1 & 27.6 & 27.6-37.6 \\ 3 & \text { do } & 61.2 & 1 & 51.2 & 51.2-61.2\end{array}$


Table 4,--Records of wells at monitoring sites--Concluded

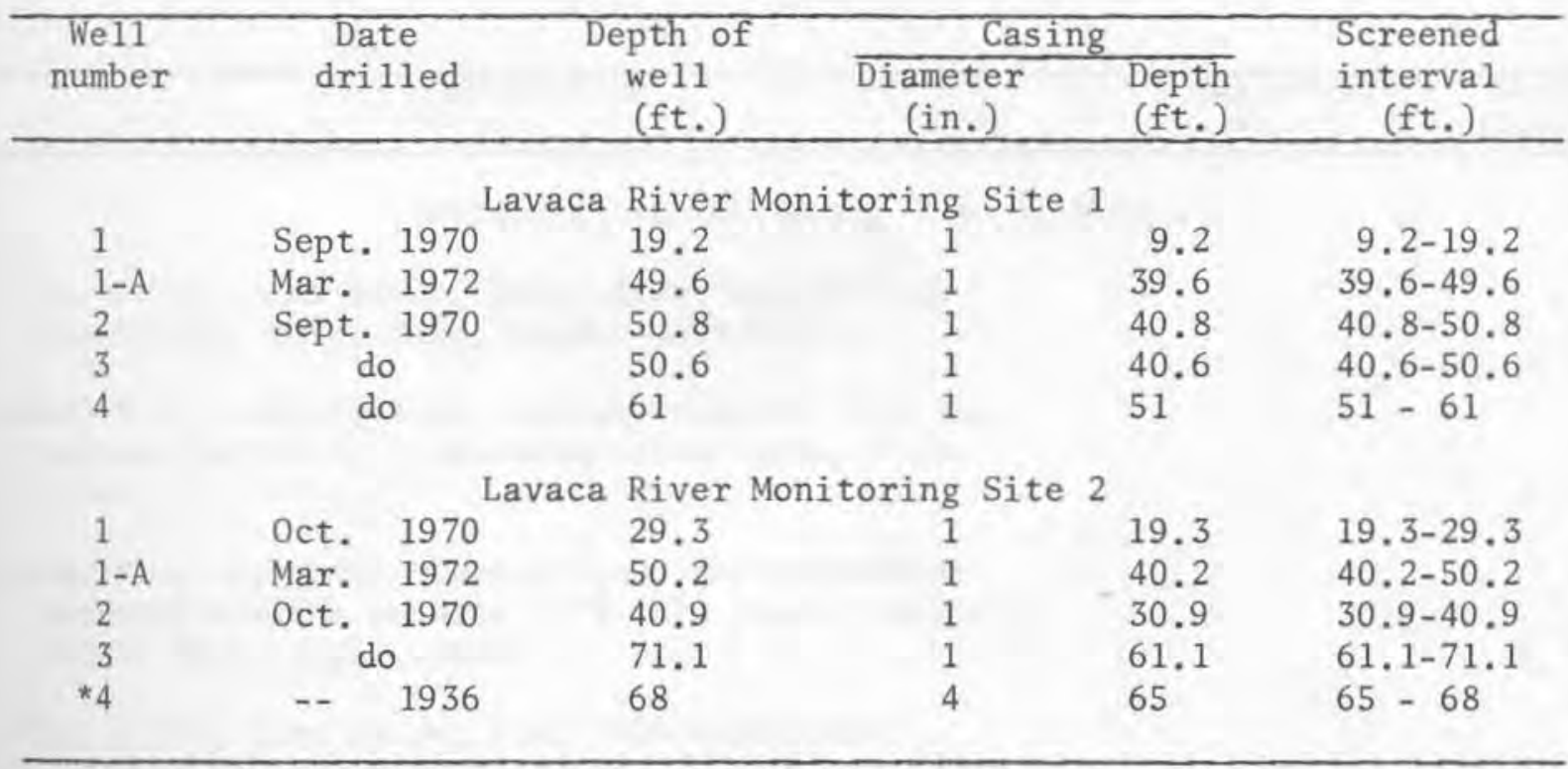

* Unused domestic water well. 
Table 5.--Drillers' logs of wells at monitoring sites

Description Thickness

Navidad River Monitoring Site 1, Well 1

Clay, silty, fine sandy, trace lime, medium high plasticity, soft, damp, black, dark brown.

Sand, fine, clayey, limy, caliche nodules ( $1 / 8$ in), medium plasticity, moderately firm, damp, light brown.

Sand, fine, slightly clayey, limy, few moderately cemented caliche nodules ( $1 / 4 \mathrm{in})$, poorly consolidated, damp, light brown.

Clay, silty, fine sandy, limy, few moderately cemented caliche nodules ( 1 in), medium plasticity, moderately firm, damp, light brown.

Sand, fine, silty to slightly silty, trace clay, limy, poorly consolidated, damp to wet, light brown. 
Table 5.--Drillers' logs of wells at monitoring sites--Continued

Navidad River Monitoring Site 1, We11 2

Clay, silty to slightly silty, 1imy 4-6 ft, medium to high plasticity, soft, damp to moist, black, dark gray.

Clay, slightly silty to silty, fine sandy, limy, medium to high plasticity, moderately tough, moderately firm, damp, reddish brown.

Clay, silty, fine sandy, limy, moderately cemented caliche nodules $(3 / 4 \mathrm{in})$, medium high plasticity, firm, damp, light brown.

Sand, fine, silty, few clay streaks, limy, poorly consolidated, damp, tan.

Clay, silty, fine sandy, limy, medium plasticity, firm, damp to moist, light brown, reddish in part.

Sand, fine to very fine, silty, slightly clayey, few clay streaks, limy, poorly consolidated, wet, tan.

Sand, fine, trace medium and coarse with fine grave 1

(3/8 in), scattered clay streaks, limy, poorly

consolidated, wet, tan. 
Table 5.--Drillers' logs of wells at monitoring sites--Continued

Navidad River Monitoring Site 1, Well 3

Clay, silty to slightly silty, fine sandy, limy with few limy nodules ( $1 / 8$ in), medium to high plasticity, soft, damp to moist, black, dark gray.

Sand, fine, clayey, silty, limy, caliche nodules

( $3 / 8$ in), medium plasticity, soft to moderately

firm, damp, light gray, brownish gray.

Clay, silty, fine sandy, limy, medium plasticity, firm, damp to moist at $28 \mathrm{ft}$, light reddish brown.

Clay, slightly silty, limy, high plasticity, tough, firm, moist, reddish brown, little gray.

Sand, fine to very fine, silty, clayey, few medium to high plasticity clay streaks, poorly consolidated, wet, light brown. 
Table 5.--Drillers' logs of wells at monitoring sites--Continued

Description

Thickness

Depth

(feet)

(feet)

Navidad River Monitoring Site 2, We11 1

Clay, fine sandy, silty, medium high plasticity, soft, damp, black.

Clay, fine sandy, silty to slightly silty, limy to very limy, caliche nodules ( $1 / 2 \mathrm{in})$, medium plasticity, moderately tough, moderately firm, damp, gray.

Sand, fine to very fine, silty, slightly clayey, limy, very limy 7-8 ft, few poorly cemented limy nodules (1/2 in), slightly consolidated, slightly damp, light $\tan , \tan$.

Sand, fine to very fine, silty, limy, few limy nodules (1/2 in), slightly consolidated, slightly damp, tan.

Clay, silty to slightly silty, fine sandy, limy, moderately cemented caliche nodules ( $3 / 4$ in), medium high plasticity, moderately tough, moderately firm, damp, gray, some red.

Clay, silty, fine sandy, limy, limy nodules (1/4 in), medium plasticity, moderately firm, damp to very damp, light brown.

Sand, fine, some medium and coarse, silty to slightly silty, poorly consolidated, wet, tan. 
Table 5.--Drillers' logs of wells at monitoring sites--Continued

\begin{tabular}{lrr}
\hline Description & $\begin{array}{r}\text { Thickness } \\
\text { (feet) }\end{array}$ & $\begin{array}{r}\text { Depth } \\
\text { (feet) }\end{array}$ \\
\hline
\end{tabular}

Navidad River Monitoring Site 2, Nell 2

Clay, silty, fine sandy, medium low plasticity, soft, damn, black.

Clay, silty, fine sandy, limy, limy nodules ( $1 / 2$ in), medium high plasticity, moderately tough, moderately firm, damp, light brown.

Clay, silty, fine sandy, limy, very limy in part, limy nodules $(1 / 4 \mathrm{in})$, medium plasticity, moderately firm, damp, light reddish brown.

Sand, fine, silty, limy, moderately cemented limy nodules (l in), slightly consolidated, slightly damp, tan.

Sand, fine, silty, clayey, medium high plastic clay streaks (3 in), slightly consolidated, slightly damp, tan, some red-brown.

Sand, fine clayey, silty, limy, slightly consolidated, damp to moist, light brown.

Sand, fine, little medium, silty, slightly clayey in part, slightly consolidated, wet, light brown. 
Table 5.--Drillers' logs of wells at monitoring sites--Continued

Description

Thickness

Depth

(feet)

(foct)

Navidad River Monitoring Site 2, Nell 3

Clay, silty to slightly silty, fine sandy, few oyster shells (road material), limy, medium high plasticity, moderately tough, soft, damp, black.

1

Clay, slightly silty to silty, fine sandy, limy, limy nodules ( $1 / 4 \mathrm{in})$, medium to high plasticity, tough, moderately firm, damp, light grayish brown.

Clay, silty, fine sandy, limy, few limy nodules ( $1 / 4$ in), medium plasticity, moderately firm, damp, light brown.

Clay, silty to slightly silty, fine sandy, limy, few limy nodules ( $1 / 4$ in), little iron stain, medium to high plasticity, moderately tough, firm, damp, gray, few black specks.

Sand, fine, slightly silty, poorly consolidated, damp, $\tan$.

Sand, fine, silty, clayey, limy, poorly consolidated, damp, $\tan$.

Sand, fine, clayey, silty, limy, medium plasticity, poorly consolidated, damp to moist, light brown.

Sand, fine, silty, poorly consolidated, wet, tan.

Navidad River Monitoring Site 3, Well 1

Sand, fine, clayey, silty, limy in part, medium plasticity, soft, damp to moist, black.

Sand, fine, silty to slightly silty, trace clay, scattered clayey streaks, limy, few limy cemented streaks ( $3 / 8 \mathrm{in})$, poorly consolidated, damp to wet, $\tan$. 
Table 5.--Drillers' logs of wells at monitoring sites--Continued

$$
\text { Description }
$$

\section{Navidad River Monitoring Site 3, Wel1 2}

Clay, silty to slightly silty, fine sandy, slightly limy, medium to high plasticity, soft, damp, black, dark gray.

Clay, silty, fine sandy, limy, medium plasticity, soft, damp, tannish, gray.

Sand, fine, silty, clayey, medium plasticity, clay streaks, slightly consolidated, damp to moist, tan.

Sand, fine, trace gravel ( $3 / 8 \mathrm{in})$, silty to slightly silty, scattered clay streaks, slightly consolidated, moist to wet, tan.

Sand, fine, clayey, clayey streaks, silty, limy, few caliche nodules ( $1 / 2$ in), poorly consolidated, wet, tan, light gray.

Navidad River Monitoring Site 3, Well 3

Clay, silty, fine sandy, medium plasticity, soft, damp to moist, dark brown.

Sand, fine, clayey, silty, limy, limy nodules (1/2 in), medium plasticity, slightly consolidated, damp, light gray.

Sand, fine, slightly silty to silty, trace clay, limy, slightly consolidated, damp 9-24 ft, moist 24-29 ft, wet 29-34 ft, $\tan$.

Sand, fine, trace medium, clayey, medium high plasticity, clay streaks, limy, poorly consolidated, tan, little pink and gray. 
Table 5.--Drillers' logs of wells at monitoring sites--Continued

\begin{tabular}{|c|c|c|}
\hline Description & $\begin{array}{l}\text { Thickness } \\
\text { (feet) }\end{array}$ & $\begin{array}{r}\text { Depth } \\
\text { (feet) }\end{array}$ \\
\hline \multicolumn{3}{|l|}{ Navidad River Monitoring Site 4, Well 1} \\
\hline $\begin{array}{l}\text { Clay, silty, fine sandy, grave } 1 \text { ( } 11 / 2 \text { in), few she } 11 \text { s, } \\
\text { medium plasticity, soft to moderately firm, damp, } \\
\text { dark brown. }\end{array}$ & 1 & 1 \\
\hline $\begin{array}{l}\text { Clay, silty to slightly silty, fine sandy, limy, medium } \\
\text { to high plasticity, soft, damp to very damp, dark gray. }\end{array}$ & 4 & 5 \\
\hline $\begin{array}{l}\text { Clay, silty, fine sandy, limy, medium high plasticity, } \\
\text { soft to moderately firm, damp to very damp, dark gray. }\end{array}$ & 8 & 13 \\
\hline $\begin{array}{l}\text { Clay, silty, fine sandy, limy, limy nodules }(1 / 2 \mathrm{in}) \text {, } \\
\text { medium high plasticity, moderately tough, firm, } \\
\text { brownish gray. }\end{array}$ & 1 & 14 \\
\hline $\begin{array}{l}\text { Sand, fine, clayey, silty, limy, poorly consolidated, } \\
\text { damp, tan. }\end{array}$ & 5 & 19 \\
\hline $\begin{array}{l}\text { Clay, silty, fine sandy, limy, limy nodules }(1 / 2 \text { in), } \\
\text { medium plasticity, moderately firm to firm, moist, tan. }\end{array}$ & 6 & 25 \\
\hline $\begin{array}{l}\text { Clay, silty, fine sandy, limy, limy nodules }(3 / 4 \mathrm{in}) \text {, } \\
\text { medium high plasticity, moderately tough, firm, } \\
\text { moist, tannish gray. }\end{array}$ & 7 & 32 \\
\hline $\begin{array}{l}\text { Sand, fine, slightly silty to silty, poorly consolidated, } \\
\text { wet, tan. }\end{array}$ & 12.4 & 44.4 \\
\hline
\end{tabular}


Table 5.--Drillers' logs of wells at monitoring sites--Continued

Navidad River Monitoring Site 4, Well 2

Clay, silty, fine sandy, limy, medium plasticity, soft, damp to moist, dark brown.

Clay, silty, fine sandy, limy, very limy with caliche streaks and nodules ( $1 / 2$ in), medium high plasticity, moderately tough, soft to moderately firm, damp to very damp, light tannish gray, some white.

Sand, fine, some medium and coarse, little gravel $(1 / 2$ in), slightly silty, medium plasticity, clay streaks, poorly consolidated, damp to moist, light tan.

Sand, fine, trace medium and coarse and gravel ( $3 / 8$ in), clay streaks, clayey, silty, limy, low to medium plasticity, poorly consolidated, moist to wet, tan.

Sand, fine, silty, slightly clayey, poorly consolidated, wet, light tan.

8.6

60.6

Navidad River Monitoring Site 4, We11 3

Sand, fine, silty, slightly clayey, soft, damp, tan.

1

Clay, silty, fine sandy, limy, medium plasticity, soft to firm, damp, light brown, gray, light reddish brown.

Sand, fine, clayey, silty, limy, low to medium plasticity, firm, damp, tan, grayish in part.

Sand, fine, slightly silty, clayey $15-18 \mathrm{ft}$, poorly consolidated, light tan.

Sand, fine, 1ittle medium and coarse, some gravel

(1/2 in), silty, clayey in part, clay balls ( 1 in), limy, poorly consolidated to consolidated, damp to moist, light $\tan$.

Sand, fine, clayey, silty, limy, few caliche nodules (1/8 in), low to medium plasticity, poorly consolidated to consolidated, tan. 
Table 5.--Drillers' logs of we1ls at monitoring sites--Continued

\section{Description}

Thickness

(feet)

Depth

(feet)

Navidad River Monitoring Site 5, Well 1

Sand, fine, silty, few roots, soft, damp, moist to wet

8-9 ft, dark brown.

Sand, fine, clayey, silty, limy, low to medium plastic-

ity, soft to slightly firm, damp, brown, gray.

Sand, fine, trace medium and coarse, slightly silty to

silty in part, slightly consolidated, damp 11-18 ft,

moist 18-23 ft, wet 23-31 ft, tan.

Navidad River Monitoring Site 5, We11 2

Sand, fine, silty, clayey, soft, damp to wet, brown.

Sand, fine, clayey, silty, limy, medium plasticity, soft to moderately firm, damp, brown, gray, little reddish brown.

Sand, fine, clayey, silty, limy to slightly limy, low plasticity, slightly consolidated, damp, tan.

Sand, fine, some medium and coarse, silty to slightly silty, slightly consolidated, damp to moist 19-26 ft, wet $26-31 \mathrm{ft}$, tan.

Sand, fine, some medium and coarse, gravel (1 $1 / 2$ in),

slightly silty, slightly consolidated, wet, tan. 
Table 5.--Drillers' logs of wells at monitoring sites--Continued

Description
(feet)

Navidad River Monitoring Site 5, Well 3

Sand, fine, silty, trace clay, soft, damp, wet $2-3 \mathrm{ft}$, brown.

Sand, fine, clayey, medium high plasticity, clay streaks, medium plasticity, soft to moderately firm, damp, brown, some gray and reddish brown.

Sand, fine, silty to slightly silty, slightly consolidated, damp to moist, tan.

Sand, fine, trace medium, silty, slightly consolidated, damp to moist, light brown.

Sand, fine, clayey, low to medium plasticity, moderately firm, damp to moist, gray, tan.

Sand, fine, very fine in part, silty, clayey, few fairly clean streaks, limy to very limy, consolidated, slightly cemented, some cemented streaks, few poorly cemented limy clay nodules ( 1 in), light gray, grayish white.

Navidad River Monitoring Site 6, Wel1 1

Sand, fine, silty, slightly clayey, limy, few small shells, few small roots, limy, soft, damp, dark brown.

Sand, fine, silty, slightly clayey, limy, few small shells, soft to slightly consolidated, damp to moist 5-15 ft, wet 15-24 ft, light brown.

Sand, fine, silty, clayey, few small she11s, limy, low plasticity, moderately firm, wet, brown. 
Table 5.--Drillers' logs of wells at monitoring sites--Continued

Navidad River Monitoring Site 6, We11 2

Clay, silty, fine sandy, limy, small roots, medium plasticity, damp, black.

Sand, fine, clayey, silty, medium plasticity, soft to moderately firm, damp, brownish gray.

Clay, silty, slightly silty in part, fine sandy, few small roots, limy, medium high plasticity, moderately tough, damp to very damp, brownish gray, gray.

Sand, fine, clayey, silty, limy, medium plasticity, soft, to moderately firm, very damp 13-16 ft, wet 16-31 ft, light brown, grayish brown.

Navidad River Monitoring Site 6, We11 3

Sand, fine, silty, slightly clayey, small roots, soft, damp to wet, light brown.

Clay, silty, fine sandy, limy, medium plasticity, moderately tough, soft to moderately firm, damp, tan, reddish brown.

Sand, fine, clayey, silty, limy, medium to low plasticity, slightly consolidated, damp reddish brown.

Sand, fine, trace gravel ( $3 / 8$ in), silty, clayey, limy, low to slight plasticity, slightly consolidated, damp to moist, light brown.

Clay, silty, fine sandy, limy, few limy nodules (1/4 in), scattered nodules ( $1 / 8$ in), medium plasticity, brownish gray.

Clay, slightly silty, fine sandy, high plasticity, tough, firm, damp, light gray.

Sand, fine, trace coarse, clayey, silty, medium to low plasticity, moderately firm, moist, grayish tan.

Sand, fine, trace medium and coarse, silty, poorly consolidated, wet, $\tan$. 
Table 5.--Drillers' logs of wells at monitoring sites--Continued

Description

Thickness

Depth

(feet)

(feet)

Navidad River Monitoring Site 7, Well 1

Sand, fine, clayey, silty, limy in part, medium plasticity, soft to moderately firm, damp, light brown, tan.

Sand, fine, little medium and coarse, trace gravel $(1 / 2$ in), slightly silty, few clay streaks, soft to slightly consolidated, damp to moist, tan.

Clay, silty, fine sandy, limy, caliche nodules ( $3 / 8$ in), medium to low plasticity, soft, moist to wet, light

brown.

Clay, slightly silty, few silty streaks, slightly fine sandy, limy, little iron stain, high plasticity, tough, firm, damp to wet, red-brown, little gray, light gray $38-47.6 \mathrm{ft}$.

Sand, fine, clayey, silty, few nodules (1/8 in), little iron stain, medium to low plasticity, soft, damp to moist, grayish brown, little yellow-brown.

Clay, fine sandy, silty, slightly silty in part, limy, caliche nodules $(1 / 2 \mathrm{in})$, few nodules ( $1 / 8 \mathrm{in})$, medium high plasticity, moderately tough, moderately firm, grayish brown.

Sand, fine, little medium and coarse, silty, few low plasticity clay streaks, limy, poorly consolidated, damp to wet, $\tan$.

Sand, fine, silty, clayey, few high plasticity clay layers ( 6 in), limy, low to medium plasticity, poorly consolidated, cemented and moderately hard 17-18 ft, wet, light brown, red in part.

Sand, fine to very fine, clayey, silty, few high plasticity clay layers, poorly consolidated, cemented and moderately hard 23-24 ft, wet, light brown.

Clay, silty to slightly silty, fine sandy, limy, medium to high plasticity, tough, moderately firm to firm, light brown, some red-brown and gray. 
Tab1e 5.--Drillers' logs of wells at monitoring sites--Continued

Navidad River Monitoring Site 7, Well 3

Sand, fine, trace gravel ( $3 / 8$ in), clayey, silty, sma11 roots, limy, soft, damp, brown.

Clay, silty to slightly silty, fine sandy, limy, few caliche nodules ( $1 / 4 \mathrm{in})$, little iron stain, medium to high plasticity, tough, moderately firm to firm, damp gray.

Clay, silty, fine sandy, limy, medium plasticity, moderately firm to firm, damp, grayish brown.

Sand, fine, clayey, silty, limy, limy nodules (1/2 in), few iron nodules (1/8 in), little iron stain 20-22 ft, medium plasticity, poorly consolidated, damp, brown, gray.

Clay, slightly silty, fine sandy, limy, iron stain 33-35 ft, high plasticity, tough, firm, damp to moist, redbrown, gray, few black silty films.

Sand, fine, clayey, silty, limy, medium plasticity, poorly consolidated, damp to moist, light brown.

Sand, fine, silty, slightly clayey, limy, poorly consolidated, wet, $\tan$.

Lavaca River Monitoring Site 1, Well 1

Sand, fine, silty, soft, damp, dark brown.

Sand, fine, some medium, slightly silty, soft to slightly consolidated, damp to wet, tan.

Clay, slightly silty, limy, high plasticity, tough, moderately firm, damp, gray.

Sand, fine, silty, little clay, poorly consolidated, wet, $\tan$. 
Table 5.--Drillers' logs of wells at monitoring sites--Continued

Description Thickness

(feet)

Lavaca River Monitoring Site 1, Well 1-A

Sand, fine, silty, soft, damp, dark brown.

Sand, fine, some medium, slightly silty, soft to

slightly consolidated, damp to wet, $\tan$.

Clay, slightly silty, limy, high plasticity, tough, moderately firm, damp, gray.

Sand, fine, silty, little clay, poorly consolidated, wet, $\tan$.

Clay, slightly sandy, with some gravel, medium plasticity, medium tough, brown.

Clay, slightly sandy, medium plasticity, medium tough, $\tan$.

Sand, fine to medium, light gray.

Lavaca River Monitoring Site 1, We11 2

Clay, slightly silty, fine sandy, high plasticity, tough, soft, damp, black.

Clay, slightly silty, fine sandy, limy, high plasticity, tough, moderately firm, damp, grayish tan.

Sand, fine, clayey with clay streaks, silty, limy, scattered limy nodules ( $1 / 2$ in), medium plasticity, firm, damp, tan, some gray.

Sand, fine, slightly silty, poorly consolidated, damp, $\tan$.

Sand, fine, clayey, clay streaks, silty, limy, little iron stain, medium plasticity, firm, damp, reddish brown, some gray.

Sand, fine, clayey, silty, medium to low plasticity, poorly consolidated, damp to moist $36-45 \mathrm{ft}$, wet $45-52.8 \mathrm{ft}$, gray. 
Table 5.--Drillers' logs of wells at monitoring sites--Continued

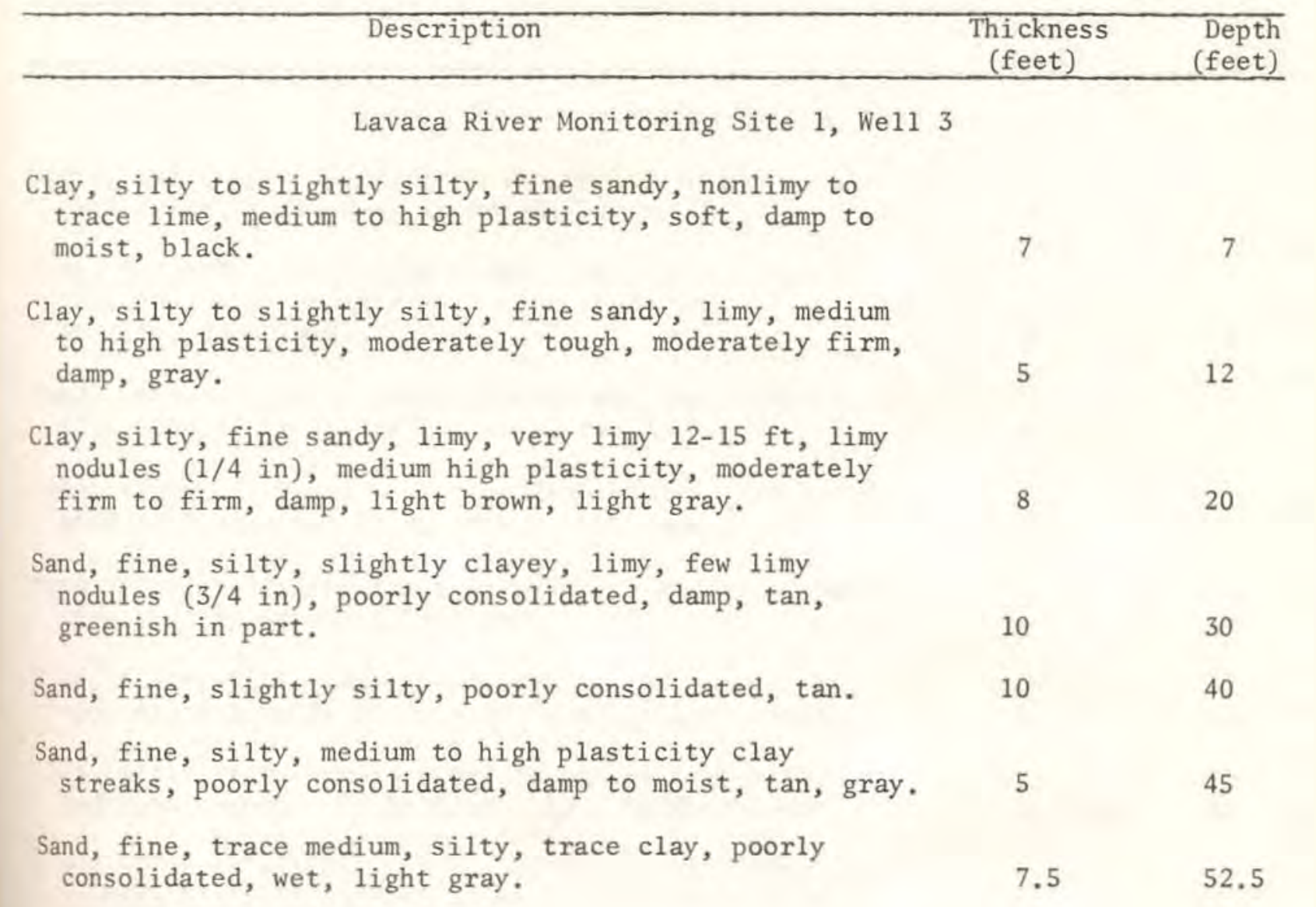


Table 5.--Drillers' logs of wells at monitoring sites--Continued

Description

Thickness

Depth

(feet)

(feet)

Lavaca River Monitoring Site 1, We11 4

Clay, silty, slightly fine sandy, medium to high plasticity, soft, damp to moist, black.

Clay, slightly silty, fine sandy, limy, limy nodules (1/4 in), high plasticity, tough, moderately firm to firm, damp, gray.

Sand, fine, silty, slightly clayey, few clay streaks, limy, poorly consolidated, damp, tan.

Clay, silty, fine sandy, limy, limy nodules (1/8 in), medium plasticity, firm, gray, light brown.

Sand, fine, silty, medium high plasticity clay streaks, limy, poorly consolidated, tan.

Clay, silty, fine sandy, limy, medium low plasticity, moderately firm to firm, damp to wet, light brown.

Clay, silty, fine sanay, limy, medium high plasticity, moderately tough, firm, damp, light reddish brown.

Clay, silty to slightly silty, silty and very fine sandy streaks 51-55 ft, medium to high plasticity, tough, firm, wet, reddish brown.

Sand, fine to very fine, silty, poorly consolidated, wet, light brown. 
Table 5.--Drillers' logs of wells at monitoring sites--Continued

Description

Thickness

Depth

(feet)

(feet)

Lavaca River Monitoring Site 2, We11 1

Clay, silty, fine sandy, limy, few small roots, medium high plasticity, moderately tough, damp, dark gray, gray.

Clay, silty, fine sandy, limy, limy nodules (1/4 in), medium plasticity, soft to moderately firm, damp 2-9 $\mathrm{ft}$, moist 9-17 ft, grayish tan.

Sand, fine, little medium and coarse, little gravel

( $3 / 8$ in) $25-29.3 \mathrm{ft}$, silty, few medium plasticity clay streaks, slightly consolidated, gray.

Lavaca River Monitoring Site 2, We11 1-A

Clay, silty, fine sandy, limy, few small roots, medium high plasticity, moderately tough, damp, dark gray.

Clay, silty, fine sandy, limy, limy nodules (1/4 in), medium plasticity, soft to moderately firm, damp 2-9 ft, grayish tan.

Sand, fine, little medium and coarse, little gravel ( $3 / 8$ in) $25-29.3 \mathrm{ft}$, silty, medium plasticity clay streaks, slightly consolidated, gray.

Sand, very coarse, with much gravel pebbles and nodules (1 to 2 in).

Sand, fine, and clay streaks, clay very sandy, light gray. 
Table 5.--Drillers' logs of wells at monitoring sites--Continued

\section{Lavaca River Monitoring Site 2, Well 2}

Sand, fine, clayey, silty, low to medium plasticity, soft, damp to wet, light brown.

Clay, silty, fine sandy, limy, iron stain, medium plasticity, moderately firm, damp, tan, gray, reddish brown.

Clay, silty, fine sandy, limy, limy nodules ( $3 / 8$ in), medium plasticity, moderately firm, damp to very damp, grayish tan.

Sand, fine, some medium and coarse, trace gravel ( $3 / 8$ in), silty to slightly silty, poorly consolidated, moist 20-26 ft, wet 26-30 ft, tan.

Sand, fine, some medium and coarse, trace gravel ( $3 / 8$ in), silty, poorly consolidated, wet, tan. 
Table 5.--Drillers' logs of wells at monitoring sites--Concluded

$$
\text { Description }
$$

\section{Lavaca River Monitoring Site 2, Well 3}

Sand, fine, clayey, silty, small roots, soft, damp, light brown.

Sand, fine, clayey, silty, limy, caliche streaks and nodules ( $1 / 2$ in), little iron stain, medium plasticity, soft to firm, damp, brown, tan, little reddish brown.

Sand, fine, little medium and coarse, silty, clayey, limy, limy nodules ( $1 / 4 \mathrm{in})$, little iron stain, slight plasticity, poorly consolidated, damp to very damp, tan.

Sand, fine, trace medium and coarse, trace gravel $(3 / 8$

in), clayey, medium to high plasticity clay streaks, limy, limy nodules (1/4 in), little iron stain, poorly consolidated, damp to very damp, tan, gray.

Sand, fine, silty to slightly silty, limy, poorly consolidated, damp to moist, tan.

Sand, fine, trace gravel ( $3 / 8$ in), silty, trace clay, poorly consolidated, wet, $\tan$. 
Table 6.--Measurements of water levels in wells and stream-surface altitudes at monitoring sites

\begin{tabular}{|c|c|c|c|c|c|c|c|c|c|c|c|c|}
\hline \multirow[b]{2}{*}{$\begin{array}{l}\text { Date of } \\
\text { measurement }\end{array}$} & \multicolumn{2}{|c|}{ Well 1} & \multicolumn{2}{|c|}{ Wel1 $1-A$} & \multicolumn{2}{|c|}{ We11 2} & \multicolumn{2}{|c|}{ We11 3} & \multicolumn{2}{|c|}{ We11 4} & \multicolumn{2}{|c|}{ Stream } \\
\hline & $\begin{array}{l}\text { Depth } \\
\text { below } \\
\text { land } \\
\text { surface } \\
\text { (ft) }\end{array}$ & $\begin{array}{l}\text { Altitude } \\
\text { from } \\
\text { arbitrary } \\
\text { datum } \\
\text { (ft) }\end{array}$ & $\begin{array}{l}\text { Depth } \\
\text { below } \\
\text { land } \\
\text { surface } \\
(\mathrm{ft})\end{array}$ & $\begin{array}{l}\text { Altitude } \\
\text { from } \\
\text { arbitrary } \\
\text { datum } \\
\text { (ft) }\end{array}$ & $\begin{array}{l}\text { Depth } \\
\text { below } \\
\text { land } \\
\text { surface } \\
(f t)\end{array}$ & $\begin{array}{l}\text { Altitude } \\
\text { from } \\
\text { arbitrary } \\
\text { datum } \\
\text { (ft) } \\
\end{array}$ & $\begin{array}{l}\text { Depth } \\
\text { below } \\
\text { land } \\
\text { surface } \\
\text { (ft) }\end{array}$ & $\begin{array}{l}\text { Altitude } \\
\text { from } \\
\text { arbitrary } \\
\text { datum } \\
\text { (ft) }\end{array}$ & $\begin{array}{l}\text { Depth } \\
\text { below } \\
\text { land } \\
\text { surface } \\
\text { (ft) }\end{array}$ & $\begin{array}{l}\text { Altitude } \\
\text { from } \\
\text { arbitrary } \\
\text { datum } \\
\text { (ft) }\end{array}$ & $\begin{array}{l}\text { Depth } \\
\text { below } \\
\text { measuring } \\
\text { point } \\
\text { (ft) }\end{array}$ & $\begin{array}{l}\text { Altitude } \\
\text { from } \\
\text { arbitrary } \\
\text { datum } \\
\text { (ft) }\end{array}$ \\
\hline \multicolumn{13}{|c|}{ NAVIDAD RIVER MONITORING SITE I } \\
\hline $11-18-70$ & 17.08 & -13.79 & & & 41.51 & -14.29 & 36.62 & -8.54 & & & 18.39 & -18.39 \\
\hline $12-10-70$ & 17.73 & -14.44 & & & 41.65 & -14.43 & 37.32 & -9.24 & & & 18.23 & $-18,23$ \\
\hline $1-11-71$ & 18.22 & -14.93 & & & 41.78 & -14.56 & 36.99 & -8.91 & & & 18.82 & -18.82 \\
\hline $2-15-71$ & 18.69 & -15.40 & & & 41.90 & -14.68 & 38.30 & -10.22 & & & 17.85 & -17.85 \\
\hline $3-23-71$ & 18.99 & -15.70 & & & 42.03 & -14.81 & 38.88 & -10.80 & & & 18.98 & -18.98 \\
\hline $4-29-71$ & 19.24 & -15.95 & & & 42.15 & -14.93 & 39.44 & -11.36 & & & 18.93 & -18.93 \\
\hline $6-2-71$ & 19.69 & -16.40 & & & 42.41 & -15.19 & 40.30 & -12.22 & & & 17.34 & -17.34 \\
\hline $7-12-71$ & 20.14 & -16.85 & & & 42.63 & -15.41 & 41.00 & -12.92 & & & 17.36 & -17.36 \\
\hline $8-10-71$ & 19.56 & -16.27 & & & 42.72 & -15.50 & 41.07 & -12.99 & & & 17.22 & -17.22 \\
\hline $8-24-71$ & 19.80 & -16.51 & & & 42.74 & -15.52 & 40.97 & -12.89 & & & 15.84 & -15.84 \\
\hline $9-14-71$ & 17.73 & $-14,44$ & & & 42.71 & -15.49 & 38.09 & -10.01 & & & a/6.90 & $a /-6.90$ \\
\hline $10-12-71$ & 18.20 & -14.91 & & & 42.47 & -15.25 & 35.68 & -7.60 & & & 17.36 & -17.36 \\
\hline $11-19-71$ & 17.93 & -14.64 & & & 42.31 & -15.09 & 34.61 & -6.53 & & & 18.26 & -18.26 \\
\hline $12-22-71$ & 18.60 & -15.31 & & & 42.15 & -14.93 & 34.31 & -6.23 & & & 18.38 & -18.38 \\
\hline $1-24-72$ & 18.10 & -14.81 & & & 42.00 & -14.78 & 34.34 & -6.26 & & & 17.65 & -17.65 \\
\hline $2-28-72$ & 17.68 & -14.39 & & & 41.90 & -14.68 & 34.90 & -6.82 & & & 18.50 & -18.50 \\
\hline $3-31-72$ & 18.24 & -14.95 & & & 41.98 & -14.76 & 35.59 & -7.51 & & & 17.41 & -17.41 \\
\hline $5-25-72$ & 15.66 & -12.37 & & & 41.74 & -14.52 & 34.84 & -6.76 & & & 17.39 & -17.39 \\
\hline $6-26-72$ & 17.28 & -13.99 & & & 41.68 & -14.46 & 34.84 & -6.76 & & & 16.76 & -16.76 \\
\hline \multicolumn{13}{|c|}{ NAVIDAD RIVER MONITORING STTE 2} \\
\hline $11-18-70$ & 23.64 & -26.95 & & & 41.65 & -26.98 & 40.71 & $-26,59$ & & & 32.19 & -32.19 \\
\hline $12-10-70$ & 24.84 & -28.15 & & & 42.43 & -27.76 & 41.47 & -27.35 & & & 32.08 & -32.08 \\
\hline $1-11-70$ & 25.56 & -28.87 & & & 43.19 & -28.52 & 42.02 & -27.90 & & & 32.18 & -32.18 \\
\hline $2-15-71$ & 26.08 & -29.39 & & & 43.71 & -29.04 & 42.54 & -28.42 & & & 32.23 & -32.23 \\
\hline $3-23-71$ & 26.44 & -29.75 & & & 44.04 & -29.37 & 42.84 & -28.72 & & & 32.17 & -32.17 \\
\hline $4-29-71$ & 26.60 & -29.91 & & & 44.24 & -29.57 & 43.10 & -28.98 & & & 31.95 & -31.95 \\
\hline $6-2-71$ & 26.90 & -30.21 & & & 44.60 & -29.93 & 43.23 & -29.11 & & & 32.17 & -32.17 \\
\hline $7-12-71$ & 27.24 & -30.55 & & & 44.96 & -30.29 & 43.42 & -29.30 & & & 29.64 & -29.64 \\
\hline $8-10-71$ & 26.14 & -29.45 & & & 44.38 & -29.71 & Dry & - & & & 23.96 & -23.96 \\
\hline $8-24-71$ & 26.44 & -29.75 & & & 44.32 & -29.65 & 43.09 & -28.97 & & & 31.33 & -31.33 \\
\hline $9-14-71$ & 24.65 & -27.96 & & & 43.62 & -28.95 & 43.30 & -29.18 & & & a/ 12.19 & a/ -12.19 \\
\hline $10-12-71$ & 24.60 & -27.91 & & & 42.76 & -28.09 & 41.58 & -27.46 & & & 30.26 & -30.26 \\
\hline $11-19-71$ & 25.16 & -28.47 & & & 43.11 & -28.44 & 41.88 & -27.76 & & & 31.96 & -31.96 \\
\hline $12-22-71$ & 24.75 & -28.06 & & & 42.80 & -28.13 & 41.18 & -27.06 & & & 31.37 & -31.37 \\
\hline $1-24-72$ & 25.39 & $-28,70$ & & & 43.19 & -28.52 & 42.40 & -28.28 & & & 31.94 & -31.94 \\
\hline $2-28-72$ & 24.75 & -28.06 & & & 42.66 & -27.99 & 41.88 & -27.76 & & & 31.58 & -31.58 \\
\hline $3-31-72$ & 25.38 & -28.69 & & & 43.22 & -28.55 & 42.35 & -28.23 & & & 31.47 & -31.47 \\
\hline $5-25-72$ & 22.44 & -25.75 & & & 40,94 & -26.27 & 40.78 & -26.66 & & & 29.90 & -29.90 \\
\hline $6-27-72$ & 23.76 & -27.07 & & & 41.86 & -27.19 & 41.14 & -27.02 & & & 30.75 & -30.75 \\
\hline
\end{tabular}

See footnotes at end of table. 
Table 6.--Measurements of water levels in wells and stream-surface altitudes at monitoring sites--Continued

\begin{tabular}{|c|c|c|c|c|c|c|c|c|c|c|c|c|}
\hline \multirow[b]{2}{*}{$\begin{array}{c}\text { Date of } \\
\text { measurement }\end{array}$} & \multicolumn{2}{|c|}{ Well 1} & \multicolumn{2}{|c|}{ We11 1-A } & \multicolumn{2}{|c|}{ Wel1 2} & \multicolumn{2}{|c|}{ Wel1 3} & \multicolumn{2}{|c|}{ We11 4} & \multicolumn{2}{|c|}{ Stream } \\
\hline & $\begin{array}{l}\text { Depth } \\
\text { below } \\
\text { land } \\
\text { surface } \\
\text { (ft) }\end{array}$ & $\begin{array}{l}\text { Altitude } \\
\text { from } \\
\text { arbitrary } \\
\text { datum } \\
\text { (ft) }\end{array}$ & $\begin{array}{l}\text { Depth } \\
\text { below } \\
\text { land } \\
\text { surface } \\
(\mathrm{ft})\end{array}$ & $\begin{array}{l}\text { Altitude } \\
\text { from } \\
\text { arbitrary } \\
\text { datum } \\
\text { (ft) }\end{array}$ & $\begin{array}{l}\text { Depth } \\
\text { below } \\
\text { land } \\
\text { surface } \\
\text { (ft) }\end{array}$ & $\begin{array}{l}\text { Altitude } \\
\text { from } \\
\text { arbitrary } \\
\text { datum } \\
\text { (ft) }\end{array}$ & $\begin{array}{l}\text { Depth } \\
\text { below } \\
\text { land } \\
\text { surface } \\
\text { (ft) }\end{array}$ & $\begin{array}{l}\text { Altitude } \\
\text { from } \\
\text { arbitrary } \\
\text { datum } \\
\text { (ft) }\end{array}$ & $\begin{array}{l}\text { Depth } \\
\text { below } \\
\text { land } \\
\text { surface } \\
(\mathrm{ft})\end{array}$ & $\begin{array}{l}\text { Altitude } \\
\text { from } \\
\text { arbitrary } \\
\text { datum } \\
\text { (ft) }\end{array}$ & $\begin{array}{l}\text { Depth } \\
\text { below } \\
\text { measuring } \\
\text { point } \\
\text { (ft) }\end{array}$ & $\begin{array}{l}\text { Altitude } \\
\text { from } \\
\text { arbitrary } \\
\text { datum } \\
\text { (ft) }\end{array}$ \\
\hline \multicolumn{13}{|c|}{ NAVIDAD RIVER MONITOR ING SITE 3} \\
\hline $12-10-70$ & 17.29 & -28.69 & & & 23.31 & -28.96 & 25.45 & -28.34 & & & $\frac{31.12}{31.17}$ & $\frac{-31.12}{-31.17}$ \\
\hline $1-11-71$ & 17.60 & -29.00 & & & 23.45 & -29.10 & 25.50 & -28.39 & & & 31.22 & -31.22 \\
\hline $2-16-71$ & 17.74 & -29.14 & & & 23.57 & -29.22 & 25.50 & -28.39 & & & 31.30 & -31.30 \\
\hline $3-23-71$ & 18.13 & -29.53 & & & 23.66 & -29.31 & 25.62 & -28.51 & & & 31.34 & -31.34 \\
\hline $4-29-71$ & 18.28 & -29.68 & & & 23.76 & -29.41 & 25.74 & -28.63 & & & 31.47 & -31.47 \\
\hline $6-2-71$ & 18.66 & -30.06 & & & 24.08 & -29.73 & 26.02 & -28.91 & & & 31.61 & -31.61 \\
\hline $7-12-71$ & 19.06 & -30.46 & & & 24.52 & -30.17 & 26.24 & -29.13 & & & 31.81 & -31.81 \\
\hline $8-10-71$ & 18.91 & -30.31 & & & 24.73 & -30.38 & 26.32 & -29.21 & & & 29.80 & -29.80 \\
\hline $8-24-71$ & 18.79 & -30.19 & & & 24.77 & -30.42 & 26.34 & -29.23 & & & 31.23 & -31.23 \\
\hline $9-14-71$ & 18.40 & -29.80 & & & 24.79 & -30.44 & 26.47 & -29.36 & & & a/ 19.81 & a) -19.81 \\
\hline $10-12-71$ & 17.65 & -29.05 & & & 24.77 & -30.42 & 26.50 & -25.61 & & & 30.69 & -30.69 \\
\hline $11-19-71$ & 18.00 & -29.40 & & & 24.70 & -30.35 & 26.57 & -29.46 & & & 31.19 & -31.19 \\
\hline $12-22-71$ & 17.47 & -28.87 & & & 24.58 & -30.23 & 26.56 & -29.45 & & & 30.62 & -30.62 \\
\hline $1-24-72$ & 17.60 & -29.00 & & & 24.44 & -30.09 & 26.48 & -29.37 & & & 30.97 & -30.97 \\
\hline $2-28-72$ & 17.14 & -28.54 & & & 24.31 & -29.96 & 26.50 & -29.39 & & & 30.74 & -30.74 \\
\hline $3-31-72$ & 17.33 & -28.73 & & & 24.26 & -29.91 & 26.45 & -29.34 & & & 27.43 & -27.43 \\
\hline $5-25-72$ & 13.05 & -24.45 & & & 23.68 & -29.33 & 26.50 & -29.39 & & & 28.94 & -28.94 \\
\hline $6-27-72$ & 15.26 & -26.66 & & & 23.57 & -29.22 & 26.56 & -29.45 & & & 30.29 & -20.29 \\
\hline \multicolumn{13}{|c|}{ NAVIDAD RIVER MONITORING SITE 4} \\
\hline $11-19-70$ & 19.69 & -28.96 & & & 31.98 & -27.68 & 41.58 & -28.91 & & & 29.95 & -29.95 \\
\hline $12-9-70$ & 19.60 & -28.87 & & & 32.40 & -28.10 & 41.66 & -28.99 & & & 29.98 & -29.98 \\
\hline $1-11-71$ & 19.80 & -29.07 & & & 32.44 & -28.14 & 41.62 & -28.95 & & & 30.03 & -30.03 \\
\hline $2-15-71$ & 20.05 & -29.32 & & & 32.63 & -28.33 & 41.75 & -29.08 & & & 30.16 & -30.16 \\
\hline $3-23-71$ & 20.27 & -29.54 & & & 32.83 & -28.53 & 41.80 & -29.13 & & & 30.29 & -30.29 \\
\hline $4-29-71$ & 20.51 & -29.78 & & & 33.01 & -28.71 & 41.96 & -29.29 & & & 30.42 & -30.42 \\
\hline $6-2-71$ & 20.96 & -30.23 & & & 33.36 & -29.06 & 42.36 & -29.69 & & & 30.59 & -30.59 \\
\hline $7-12-71$ & 21.44 & -30.71 & & & 33.76 & -29.46 & 42.86 & -30.19 & & & 30.80 & -30.80 \\
\hline $8-10-71$ & 20.04 & -29.31 & & & 33.94 & -29.64 & 42.98 & -30.31 & & & 29.04 & -29.04 \\
\hline $8-24-71$ & 21.20 & -30.47 & & & 34.18 & -29.88 & 43.23 & -30.56 & & & 30.18 & -30.18 \\
\hline $9-14-71$ & 19.81 & -29.08 & & & 33.05 & -28.75 & 43.02 & -30.35 & & & 26.82 & -26.82 \\
\hline $10-12-71$ & 20.78 & -30.05 & & & 33.95 & -29.65 & 43.12 & -30.45 & & & 29.84 & -29.84 \\
\hline $11-19-71$ & 21.11 & -30.38 & & & 34.36 & -30.06 & 43.10 & -30.43 & & & 30.15 & -30.15 \\
\hline $12-22-71$ & 20.67 & -29.94 & & & 33.92 & -29.62 & 43.05 & -30.38 & & & 29.59 & -29.59 \\
\hline $1-24-72$ & 20.50 & -29.77 & & & 34.06 & -29.76 & 42.90 & -30.23 & & & 29.92 & -29.92 \\
\hline $2-28-72$ & 20.32 & -29.59 & & & 33.78 & -29.48 & 42.80 & -30.13 & & & 29,70 & -29.70 \\
\hline $3-31-72$ & 20.17 & -29.44 & & & 33.58 & -29.28 & 42.86 & -30.19 & & & 29.50 & -29.50 \\
\hline $5-25-72$ & $\mathrm{~b} / 16.47$ & b $/-25.74$ & & & 31.55 & -27.25 & 42.73 & -30.06 & & & 28.72 & -28.72 \\
\hline $6-26-72$ & 18.10 & -27.37 & & & 31.61 & -27.31 & 41.77 & -29.10 & & & 29.70 & -29.70 \\
\hline
\end{tabular}

See footnotes at end of table. 
Table 6.--Measurements of water levels in wells and stream-surface altitudes at monitoring sites--Continued

\begin{tabular}{|c|c|c|c|c|c|c|c|c|c|c|c|c|}
\hline $\begin{array}{l}\text { Date of } \\
\text { measurement }\end{array}$ & $\begin{array}{l}\text { We } \\
\text { Depth } \\
\text { below } \\
\text { I and } \\
\text { surface } \\
\text { (ft) }\end{array}$ & $\begin{array}{l}1 \\
\text { Altitude } \\
\text { from } \\
\text { arbitrary } \\
\text { datum } \\
\text { (ft) }\end{array}$ & $\begin{array}{l}\text { We } \\
\text { Depth } \\
\text { below } \\
\text { land } \\
\text { surface } \\
\text { (ft) }\end{array}$ & $\begin{array}{l}\text { Altitude } \\
\text { from } \\
\text { arbitrary } \\
\text { datum } \\
\text { (ft) }\end{array}$ & $\begin{array}{l}\text { Wepth } \\
\text { below } \\
\text { land } \\
\text { surface } \\
\text { (ft) }\end{array}$ & $\begin{array}{l}12 \\
\text { Altitude } \\
\text { from } \\
\text { arbitrary } \\
\text { datum } \\
\text { (ft) }\end{array}$ & $\begin{array}{l}\text { We } \\
\text { Depth } \\
\text { below } \\
\text { land } \\
\text { surface } \\
(\mathrm{ft})\end{array}$ & $\begin{array}{l}13 \\
\text { Altitude } \\
\text { from } \\
\text { arbitrary } \\
\text { datum } \\
\text { (ft) }\end{array}$ & $\begin{array}{l}\text { W } \\
\text { Depth } \\
\text { below } \\
\text { land } \\
\text { surface } \\
\text { (ft) }\end{array}$ & $\begin{array}{l}4 \\
\text { Altitude } \\
\text { from } \\
\text { arbitrary } \\
\text { datum } \\
\text { (ft) }\end{array}$ & $\begin{array}{l}\text { Stz } \\
\text { Depth } \\
\text { below } \\
\text { measuring } \\
\text { point } \\
\text { (ft) }\end{array}$ & $\begin{array}{l}\text { Altitude } \\
\text { from } \\
\text { arbitrary } \\
\text { datum } \\
\text { (ft) } \\
\end{array}$ \\
\hline \multicolumn{13}{|c|}{ NAVIDAD RIVER MONITORING SITE 5} \\
\hline $12-9-70$ & 22.04 & -17.35 & & & 25.25 & -18.82 & 50.24 & -43.80 & & & 18.86 & -18.86 \\
\hline $1-11-71$ & 22.39 & -17.70 & & & 25.43 & -19.00 & 49.47 & -42.99 & & & 18.89 & -18.89 \\
\hline $2-15-71$ & 22.67 & -17.98 & & & 25.59 & -19.16 & 48.63 & $-42,15$ & & & 19.02 & -19.02 \\
\hline $3-23-71$ & 22.89 & -18.20 & & & 25.78 & -19.35 & 47.85 & -41.37 & & & 19.06 & -19.06 \\
\hline $4-29-71$ & 23.08 & -18.39 & & & 25.92 & -19.49 & 48.41 & -41.93 & & & 19.21 & -19.21 \\
\hline $6-2-71$ & 23.43 & -18.74 & & & 26.22 & -19.79 & 50,30 & -43.82 & & & 19.39 & -19.39 \\
\hline $7-12-71$ & 23.88 & -19.19 & & & 26.59 & -20.16 & 52.40 & -45.92 & & & 19.60 & -19.60 \\
\hline $8-11-71$ & 23.46 & -18.77 & & & 26.84 & -20.41 & 53.56 & -47.08 & & & 18.23 & -18.23 \\
\hline $8-24-71$ & 23.71 & -19.02 & & & 26.87 & -20.44 & 53.82 & -47.34 & & & 19.02 & -19.02 \\
\hline $9-14-71$ & 23.16 & -18.47 & & & 27.05 & -20.62 & 54.40 & -47.92 & & & 17.28 & -17.28 \\
\hline $10-12-71$ & 23.08 & -18.39 & & & 26.92 & -20.49 & 55.60 & -49.20 & & & 18.78 & -18.78 \\
\hline $11-19-71$ & 23.16 & -18.47 & & & 26.84 & -20.41 & 54.49 & -48.01 & & & 18.81 & -18.81 \\
\hline $12-22-71$ & 22.70 & -18.01 & & & 26.70 & -20.27 & 53.83 & -47.35 & & & 18.34 & -18.34 \\
\hline $1-24-72$ & 22.70 & -18.01 & & & 26.36 & -19.93 & 52.24 & -45.76 & & & 18.69 & -18.69 \\
\hline $2-28-72$ & 21.94 & -17.25 & & & 26.22 & -19.79 & 50.57 & -44.09 & & & 18.43 & -18.43 \\
\hline $3-31-72$ & 21.77 & -17.08 & & & 25.80 & -19.37 & 50.14 & -43.66 & & & 18.17 & -18.17 \\
\hline $5-26-72$ & 14.77 & -10.08 & & & 24.75 & -18.32 & 51.02 & -44.54 & & & 17.73 & -17.73 \\
\hline $6-26-72$ & 17.38 & -12.69 & & & 23.34 & -16.91 & 51.52 & -45.04 & & & 18.44 & -18.44 \\
\hline \multicolumn{13}{|c|}{ NAVIDAD RIVER MONITORING SITE 6} \\
\hline $11-20-70$ & 14.74 & -23.99 & & & 12.05 & -22.25 & 28.24 & -20.09 & & & 27.86 & -27.86 \\
\hline $12-9-70$ & 14.96 & -24.21 & & & 12.32 & -22.52 & 28.40 & -20.25 & & & 27.90 & -27.90 \\
\hline $1-11-71$ & 15.20 & -24.45 & & & 12.59 & -22.79 & 28.47 & -20.32 & & & 27.90 & -27.90 \\
\hline $2-15-71$ & 15.36 & -24.61 & & & 12.76 & -22.96 & 28.64 & -20.49 & & & 28.08 & -28.08 \\
\hline $3-23-71$ & 15.48 & -24.73 & & & 12.97 & -23.17 & 28.73 & -20.58 & & & 28.14 & -28.14 \\
\hline $4-29-71$ & 15.65 & -24.90 & & & 13.01 & -23.21 & 28.84 & -20.69 & & & 28.41 & -28.41 \\
\hline $6-2-71$ & 16.12 & -25.37 & & & 13.35 & -23.55 & 29.04 & -20.89 & & & 28.54 & -28.54 \\
\hline $7-13-71$ & 16.58 & -25.83 & & & 13.85 & -24.05 & 29.37 & -21.22 & & & 28.55 & -28.55 \\
\hline $8-11-71$ & 14.04 & -23.29 & & & 13.07 & -23.27 & 29.43 & -21.28 & & & 27.50 & -27.50 \\
\hline $8-25-71$ & 15.28 & -24.53 & & & 12.98 & -23.18 & 29.38 & -21.23 & & & 28.28 & -28.28 \\
\hline $9-15-71$ & 12.48 & -21.73 & & & 12.40 & -22.60 & 29.37 & -21.22 & & & 26.79 & -26.79 \\
\hline $10-12-71$ & 14.23 & -23.48 & & & 11.83 & -22.03 & 29.22 & -21.07 & & & 27.74 & -27.74 \\
\hline $11-19-71$ & 14.51 & -23.76 & & & 12.07 & -22.27 & 28.97 & -20.82 & & & 26.08 & -26.08 \\
\hline $12-22-71$ & 13.46 & -22.71 & & & 11.21 & -21.41 & 28.80 & -20.65 & & & 27.08 & -27.08 \\
\hline $1-24-72$ & 13.80 & -23.05 & & & 11.08 & -21.28 & 28.54 & -20.39 & & & 27.29 & -27.29 \\
\hline $2-28-72$ & 13.07 & -22.32 & & & 10.45 & -20.65 & 28.18 & -20.03 & & & 27.07 & -27.07 \\
\hline $3-31-72$ & 12.83 & -22.08 & & & 10.40 & -20.60 & 28.04 & -19.89 & & & 26.83 & -26.83 \\
\hline $5-26-72$ & 10.24 & -19.49 & & & 7.26 & -17.46 & 27.60 & -19.45 & & & 26.30 & -26.30 \\
\hline $6-26-72$ & 12.45 & -21.70 & & & 9.44 & -19.64 & 27.35 & -19.20 & & & 27.16 & -27.16 \\
\hline
\end{tabular}

See footnotes at end of table. 
Table 6.--Measurements of water levels in wel1s and stream-surface altitudes at monitoring sites--Continued

\begin{tabular}{|c|c|c|c|c|c|c|c|c|c|c|c|c|}
\hline \multirow[b]{2}{*}{$\begin{array}{l}\text { Date of } \\
\text { measurement }\end{array}$} & \multicolumn{2}{|c|}{ We11 1} & \multicolumn{2}{|c|}{ WeI1 $1-A$} & \multicolumn{2}{|c|}{ WeII 2} & \multicolumn{2}{|c|}{ We11 3} & \multicolumn{2}{|c|}{ We11 4} & \multicolumn{2}{|c|}{ Stream } \\
\hline & $\begin{array}{l}\text { Depth } \\
\text { below } \\
\text { land } \\
\text { surface } \\
\text { (ft) }\end{array}$ & $\begin{array}{l}\text { Altitude } \\
\text { from } \\
\text { arbitrary } \\
\text { datum } \\
\text { (ft) }\end{array}$ & $\begin{array}{l}\text { Depth } \\
\text { below } \\
\text { land } \\
\text { surface } \\
(\mathrm{ft})\end{array}$ & $\begin{array}{l}\text { Altitude } \\
\text { from } \\
\text { arbitrary } \\
\text { datum } \\
\text { (ft) }\end{array}$ & $\begin{array}{l}\text { Depth } \\
\text { below } \\
\text { land } \\
\text { surface } \\
\text { (ft) }\end{array}$ & $\begin{array}{l}\text { Altitude } \\
\text { from } \\
\text { arbitrary } \\
\text { datum } \\
\text { (ft) }\end{array}$ & $\begin{array}{l}\text { Depth } \\
\text { below } \\
\text { land } \\
\text { surface } \\
\text { (ft) }\end{array}$ & $\begin{array}{l}\text { Altitude } \\
\text { from } \\
\text { arbitrary } \\
\text { datum } \\
\text { (ft) }\end{array}$ & $\begin{array}{l}\text { Depth } \\
\text { below } \\
\text { land } \\
\text { surface } \\
\text { (ft) }\end{array}$ & $\begin{array}{l}\text { Altitude } \\
\text { from } \\
\text { arbitrary } \\
\text { datum } \\
\text { (ft) }\end{array}$ & $\begin{array}{l}\text { Depth } \\
\text { below } \\
\text { measuring } \\
\text { point } \\
(\mathrm{ft})\end{array}$ & $\begin{array}{l}\text { Altitude } \\
\text { from } \\
\text { arbitrary } \\
\text { datum } \\
\text { (ft) } \\
\end{array}$ \\
\hline \multicolumn{13}{|c|}{ NAVIDAD RIVER MONITORING SITE 7} \\
\hline $11-20-70$ & 19.42 & +3.72 & & & 6.89 & +19.47 & 33.52 & +3.52 & & & 4.91 & -5.09 \\
\hline $12-9-70$ & 19.92 & +3.22 & & & 9.08 & +17.28 & 33.62 & +3.42 & & & 4.85 & -5.15 \\
\hline $1-11-71$ & 20.18 & +2.96 & & & 10.63 & +15.73 & 33.77 & +3.27 & & & 4.84 & -5.16 \\
\hline $2-15-71$ & 20.57 & +2.57 & & & 11.73 & +14.63 & 33.94 & +3.10 & & & 4.73 & -5.27 \\
\hline $3-23-71$ & 20.92 & +2.22 & & & 12.45 & +13.91 & 34.07 & +2.97 & & & 4.67 & -5.33 \\
\hline $4-28-71$ & 21.21 & +1.93 & & & 13.00 & +13.36 & 33.98 & +3.06 & & & 4.43 & -5.57 \\
\hline $6-2-71$ & 21.76 & +1.38 & & & 13.56 & +12.80 & 34.56 & +2.48 & & & 4.30 & -5.70 \\
\hline $7-13-71$ & 22.38 & +.76 & & & 14.18 & +12.18 & 34.92 & +2.12 & & & 4.20 & -5.80 \\
\hline $8-11-71$ & 22.16 & +.98 & & & 14.50 & +11.86 & 33.71 & +3.33 & & & 5.46 & -4.54 \\
\hline $8-24-71$ & 21.62 & +1.52 & & & 14.66 & +11.70 & 34.04 & +3.00 & & & 4.53 & -5.47 \\
\hline $9-15-71$ & 21.47 & +1.67 & & & 15.99 & $+10,37$ & 32.95 & +4.09 & & & 5.52 & -4.42 \\
\hline $10-12-71$ & 20.38 & +2.76 & & & 16.00 & +10.36 & 38.08 & +3.96 & & & 4.87 & -5.13 \\
\hline $11-19-71$ & 19.42 & +3.72 & & & 15.92 & +10.44 & 33.64 & +3.40 & & & 5.42 & -4.58 \\
\hline $12-22-71$ & 20.04 & $+3,10$ & & & 15.86 & +10.50 & 33.03 & +4.01 & & & 5.25 & -4.75 \\
\hline $1-24-72$ & 19.86 & +3.28 & & & 15.78 & +10.58 & 33.00 & +4.04 & & & 5.04 & -4.96 \\
\hline $2-28-72$ & 19.56 & +3.58 & & & 15.78 & +10.58 & 32.56 & +4.48 & & & 5.10 & -4.90 \\
\hline $3-31-72$ & 19.20 & +3.94 & & & 15.72 & +10.64 & 32.37 & +4.67 & & & 5.22 & -4.88 \\
\hline $5-26-72$ & 17.70 & +5.44 & & & 15.42 & +10.94 & 31.44 & +5.60 & & & 5.58 & $-4,42$ \\
\hline $6-26-72$ & 18.60 & +4.54 & & & 15.33 & +11.03 & 32.01 & +5.03 & & & 4.89 & -5.11 \\
\hline \multicolumn{13}{|c|}{ LAVACA RIVER MONITORING SITE 1} \\
\hline $11-18-70$ & 7.37 & -7.13 & & & 42.49 & -23.01 & 45.12 & $-23,24$ & 36.94 & -15.11 & 27.22 & -27.22 \\
\hline $12-10-70$ & 8.05 & -7.81 & & & 42.78 & -23.30 & 45.34 & -23.46 & 36.98 & -15.15 & 26.78 & -26.78 \\
\hline $1-11-71$ & 8.68 & -8.44 & & & 42.92 & -23.44 & 45.33 & -23.45 & 36.98 & -15.15 & 27.24 & -27.24 \\
\hline $2-15-71$ & 9.69 & -9.45 & & & 43.12 & -23.64 & 45.40 & -23.52 & 36.98 & -15.15 & 26.74 & -26.74 \\
\hline $3-23-71$ & 9.98 & -9.74 & & & 43.26 & -23.78 & 45.45 & -23.57 & 36.99 & -15.16 & 27.67 & -27.67 \\
\hline $4-29-71$ & 10.34 & -10.10 & & & 43.52 & -24.04 & 45.80 & -23.92 & 36.96 & -15.13 & 26,48 & -26.48 \\
\hline $6-2-71$ & 11.03 & -10.79 & & & 43.94 & -24.46 & 46.42 & -24.54 & 37.12 & -15.29 & 26.27 & -26.27 \\
\hline $7-12-71$ & 11.18 & -10.94 & & & 44.37 & -24.89 & 47.00 & -25.12 & 37.28 & -15.45 & 26.25 & -26.25 \\
\hline $8-10-71$ & 9.50 & -9.26 & & & 44.50 & -25.02 & 47.24 & -25.36 & 37.30 & -15.47 & 25.27 & -25.27 \\
\hline $8-23-71$ & 9.24 & -9.00 & & & 44.51 & -25.03 & 47.17 & -25.29 & 37.30 & -15.47 & 26.24 & -26.24 \\
\hline $9-14-71$ & 5.83 & -5.59 & & & 44.52 & -25.04 & 47.16 & -25.30 & 37.50 & -15.67 & a $/ 7.40$ & a $/-7.40$ \\
\hline $10-12-71$ & 6.67 & -6.43 & & & 43.27 & -23.79 & 45.96 & -24.08 & 37.38 & -15.55 & 25.99 & -25.99 \\
\hline $11-19-71$ & 6.31 & -6.07 & & & 42.58 & -23.10 & 45.40 & -23.52 & 39.36 & -15.53 & 26.65 & -26.65 \\
\hline $12-22-71$ & 6.43 & -6.19 & & & 42.20 & -22.72 & 44.94 & -23.06 & 37.18 & -15.35 & 26.52 & -26.52 \\
\hline $1-24-72$ & 7.21 & -6.97 & & & 41.96 & -22.48 & 44.60 & -22.72 & 37.00 & -15.17 & 26.37 & -26.37 \\
\hline $2-28-72$ & 7.50 & -7.26 & First & reading & 41.80 & -22.32 & 44.21 & -22.33 & 36.97 & -15.14 & 26.74 & -26.74 \\
\hline $3-31-72$ & 8.11 & -7.87 & 20.98 & -20.76 & 41.99 & -22.51 & 44.38 & -22.50 & 36.96 & -15.13 & 26.04 & -26.04 \\
\hline $5-25-72$ & 5.76 & -5.52 & 15.37 & -15.15 & 38.99 & -19.51 & 41.36 & -19.48 & 36.84 & -15.01 & 24.93 & -24.93 \\
\hline $6-26-72$ & 7.24 & -7.00 & 13.31 & -16.09 & 39.98 & -20.50 & 42.90 & -21.02 & c) & c) & 25.58 & -25.58 \\
\hline
\end{tabular}


Table 6.--Measurements of water levels in wel1s and stream-surface altitudes at monitoring sites--Concluded

\begin{tabular}{|c|c|c|c|c|c|c|c|c|c|c|c|c|}
\hline \multirow[b]{2}{*}{$\begin{array}{c}\text { Date of } \\
\text { measurement }\end{array}$} & \multicolumn{2}{|c|}{ Well 1} & \multicolumn{2}{|c|}{ We11 1-A } & \multicolumn{2}{|c|}{ We11 2} & \multicolumn{2}{|c|}{ We11 3} & \multicolumn{2}{|c|}{ We11 4} & \multicolumn{2}{|c|}{ Stream } \\
\hline & $\begin{array}{l}\text { Depth } \\
\text { below } \\
\text { land } \\
\text { surface } \\
\text { (ft) }\end{array}$ & $\begin{array}{l}\text { Altitude } \\
\text { from } \\
\text { arbitrary } \\
\text { datum } \\
\text { (ft) }\end{array}$ & $\begin{array}{l}\text { Depth } \\
\text { below } \\
\text { land } \\
\text { surface } \\
(\mathrm{ft})\end{array}$ & $\begin{array}{l}\text { Altitude } \\
\text { from } \\
\text { arbitrary } \\
\text { datum } \\
\text { (ft) }\end{array}$ & $\begin{array}{l}\text { Depth } \\
\text { below } \\
\text { land } \\
\text { surface } \\
\text { (ft) }\end{array}$ & $\begin{array}{l}\text { Altitude } \\
\text { from } \\
\text { arbitrary } \\
\text { datum } \\
\text { (ft) }\end{array}$ & $\begin{array}{l}\text { Depth } \\
\text { below } \\
\text { land } \\
\text { surface } \\
(\mathrm{ft})\end{array}$ & $\begin{array}{l}\text { Altitude } \\
\text { from } \\
\text { arbitrary } \\
\text { datum } \\
\text { (ft) }\end{array}$ & $\begin{array}{l}\text { Depth } \\
\text { below } \\
\text { land } \\
\text { surface } \\
\text { (ft) }\end{array}$ & $\begin{array}{l}\text { Altitude } \\
\text { from } \\
\text { arbitrary } \\
\text { datum } \\
\text { (ft) }\end{array}$ & $\begin{array}{l}\text { Depth } \\
\text { below } \\
\text { measuring } \\
\text { point } \\
\text { (ft) }\end{array}$ & $\begin{array}{l}\text { Altitude } \\
\text { from } \\
\text { arbitrary } \\
\text { datum } \\
\text { (ft) } \\
\end{array}$ \\
\hline \multicolumn{13}{|c|}{ LAVACA RIVER MONITORING SITE 2} \\
\hline $11-19-70$ & 16.97 & -29.87 & & & 24.32 & -28.73 & 51.97 & -35.94 & -- & $\cdots$ & 31.73 & -31.73 \\
\hline $12-10-70$ & 17.25 & -30.15 & & & 24.58 & -28.99 & 51.37 & -35.34 & -- & $\cdots$ & 31.66 & -31.66 \\
\hline $1-11-71$ & 17.47 & -30.37 & & & 24.67 & -29.08 & 50.47 & -34.44 & -- & $\cdots$ & 31.69 & -31.69 \\
\hline $1-22-71$ & 17.49 & -30.39 & & & 24.71 & -29.12 & 50.17 & -34.14 & 48.27 & -36.15 & 31.66 & -31.66 \\
\hline $2-15-71$ & 17.61 & -30.51 & & & 24.91 & -29.32 & 49.69 & -33.66 & 47.71 & -35.59 & 31.80 & -31.80 \\
\hline $3-23-71$ & 17.70 & -30.60 & & & 25.06 & -29.47 & 49.37 & -33.34 & 47.16 & -35.04 & 31.87 & -31.87 \\
\hline $4-29-71$ & 17.93 & -30.83 & & & 25.16 & -29.57 & 52.34 & -36.31 & 50.20 & -38.08 & 31.82 & -31.82 \\
\hline $6-2-71$ & 17.31 & -31.21 & & & 25.38 & -29.79 & 55.37 & -39.34 & 54.47 & -42.35 & 32.11 & -32.11 \\
\hline $7-12-71$ & 18.50 & -31.40 & & & 25.63 & -30.04 & 57.32 & -41.29 & 55.94 & -43.82 & 32.08 & -32.08 \\
\hline $8-10-71$ & 15.91 & -28.81 & & & 25.71 & -30.12 & 57.95 & -41.92 & 56.56 & -44.44 & 29.74 & -29.74 \\
\hline $8-23-71$ & 16.81 & -29.71 & & & 25.69 & -30.10 & 57.27 & -41.24 & 56.45 & -44.33 & 31.22 & -31.22 \\
\hline $9-14-71$ & 10.45 & -23.35 & & & 25.63 & -30.04 & 55.80 & -39.77 & 55.92 & -43.80 & 26.93 & -26.93 \\
\hline $10-12-71$ & 14.78 & -27.68 & & & 26.15 & -30.56 & 54.69 & -38.66 & 55.09 & -42.97 & 31.04 & -31.04 \\
\hline $11-19-71$ & 16.06 & -28.96 & & & 24.92 & -29.33 & 53.04 & -37.01 & 52.79 & -40.67 & 31.23 & -31.23 \\
\hline $12-22-71$ & 15.34 & -28.24 & & & 24.77 & -29.18 & 51.64 & -35.61 & 51.21 & -39.09 & 30.92 & -30.92 \\
\hline $1-24-72$ & 16.22 & -29.12 & & & 24.62 & -29.03 & 50.68 & -34.65 & 50.02 & -37.90 & 31.35 & -31.35 \\
\hline $2-28-72$ & 15.37 & -28.27 & First & reading & 24.39 & -28.80 & 49.60 & -33.57 & 48.79 & -36.67 & 31.14 & -31.14 \\
\hline $3-31-72$ & 15.93 & -28.83 & 15.13 & -28.79 & 24.34 & -28.75 & 49.94 & -33.91 & 48.46 & -36.34 & 31.17 & -31.17 \\
\hline $5-25-72$ & 10.84 & -23.74 & $\mathrm{~b} / 4.16$ & $\mathrm{~b} /-17.82$ & 23.54 & -27.95 & 51.42 & -35.39 & 50.96 & -38.84 & 29.13 & -29.13 \\
\hline $6-26-72$ & 13.98 & -26.88 & 9.32 & -22.98 & 23.48 & -27.89 & 53.50 & -37.47 & 52.38 & -40.26 & 30.06 & -30.06 \\
\hline
\end{tabular}

a) Flood stage,

b/ Well recently submerged by floodwater.

c/ Well casing bent badly, no measurement. 